\title{
WELFARE PROGRAM ORGANIZATION AND LEGITIMACY A comparison of eleven OECD countries
}

\author{
ORGANIZACIÓN Y LEGITIMIDAD DE LOS PROGRAMAS DE BIENESTAR \\ Análisis comparado de once países de la OCDE
}

InÉs CALZADA ines.calzada@cchs.csic.es

Instituto de Políticas y Bienes Públicos (IPP-CCHS-CSIC). Madrid. Spain

\begin{abstract}
The main objective of this paper is to analyze the relationship between the institutionalisation of the Welfare State and its legitimacy, that is, until what extent the way of organising welfare programs have an impact on citizen's perceptions of these programs and, hence, on the size and composition of the legitimacy basis of the Welfare State. In order to comply with this objective the paper is organised as follows: first we will present data showing the cross-country variation in support for three main welfare programs (health care, old-age pensions, unemployment benefits); then we will analyse until what extent high levels of legitimacy are achieved through cross-class coalitions or cross-ideology coalitions. Finally we evaluate the impact of different program characteristics on the aggregate level of popular support each program achieves.
\end{abstract}

\section{KEYWORDS}

Attitudes to welfare policies; Institutionalism; Public opinion; Welfare Regimes.

\section{RESUMEN}

El objetivo principal de este artículo es analizar la relación entre la institucionalización del Estado del Bienestar y su legitimidad, es decir, hasta qué punto la forma de organizar el Estado de Bienestar afecta a las percepciones que los ciudadanos desarrollan sobre el mismo y, de esta manera, modifica el tamaño y composición de sus bases de apoyo. A fin de cumplir con este objetivo el artículo se estructura de la siguiente forma: en primer lugar presentamos un panorama de la variación internacional en las actitudes hacia tres programas de bienestar (sanidad, pensiones y desempleo). Seguidamente estudiaremos de dónde proviene el apoyo extra que algunos programas consiguen, centrándonos específicamente en comprobar si se logra una mayor legitimidad mediante la construcción de consensos inter-clases o inter-ideologías. Terminaremos evaluando qué características organizativas concretas son las que correlacionan con el nivel de apoyo popular que un programa recibe.

\section{Palabras clave}

Actitudes hacia las políticas sociales; Institucionalismo; Opinión pública; Regímenes de bienestar. 


\section{INTRODUCTION}

The first studies on citizens' attitudes toward the Welfare State (WS) started some 30 years ago. In this time, public and academic interest on the topic has grown steadily. One of the reasons behind the success of this research area may have to do with the crucial role played by public opinion during the "crisis of the WS" which occurred in the 1990s. Although many economic think-tanks forecast grim futures for the WS, most WS's reached the new millennium with the majority of their pieces still intact. Scholars such as Ramesh Mishra (1996) and Peter Taylor-Gooby (2003) have explained this surprising resilience by pointing to public opinion polls, which throughout this decade, have shown politicians that the electoral cost of reducing the WS could potentially be too high.

Legitimacy is important for the survival of any democratic institution, but this is especially true for the WS. Due to its sizeable effect on inequalities and on employer/employee equilibriums, this institution has lived under permanent cross-fire since its birth. More often than not, legitimacy comes into play as a force that restrains or initiates change. We have now reached a point in history in which almost every actor in the social policy arena is concerned with the legitimacy of public policies. However, it remains unclear what course of action could be taken to shape popular attitudes. For instance, can the government act in a way that increases (or decreases) the legitimacy basis of the WS? It has been demonstrated that public opinion has a strong impact on the WS, but is it possible that the WS also shapes public opinion? Furthermore, is there a way to organize welfare programs that increases popular support for the WS?

This paper attempts to shed light on these questions by analyzing various mechanisms behind welfare state legitimacy from a neo-institutionalist perspective. Our aim is to analyze the relationship between the institutionalization of the WS and its legitimacy. In other words, we seek to understand how the organization of welfare programs influences citizen perceptions of such programs.

In order to comply with this objective, the paper is organized in the following manner. The first two sections contain the theoretical framework, hypotheses, and methods. We then present the data analysis which starts with a comparison of citizen's attitudes toward welfare programs across eleven countries to determine where they achieve more popular support. Once this "legitimacy" ranking is developed and verified, we proceed to study the composition of support for welfare programs in each individual country. Specifically, we analyze to what extent high levels of legitimacy are achieved through cross-class coalitions, through cross-ideology coalitions, or both. Finally, we evaluate the impact of different characteristics of welfare programs on their aggregate level of support.

\footnotetext{
"This research has been developed in the framework of the cooperative project "Welfare Attitudes in a Changing Europe", supported by the European Science Foundation and the Spanish Ministry of Science and Innovation
} 


\section{THEORETICAL DISCUSSION AND HYPOTHESES}

A large share of studies on welfare attitudes have attempted to understand variations in support for the WS, at both the micro-level (among individuals) and the macro-level (among countries). At the micro-level, different studies established that attitudes to the WS have two general determinants: "self-interest" and "ideology" (Svallfors, 1997, 2000; Forma, 1999; Andreß \& Heien, 2001; Lipsmeyer \& Nordstrom, 2003; Fraile \& Ferrer, 2004). Self-interest refers to the economic interest an individual has in the existence of welfare programs. Analyses performed in almost all OECD countries show that, on the whole, low income groups and those more dependent on public programs for the provision of welfare services are more prone to support the WS than are high income groups and those with less risk of welfare dependency.

The second determinant, ideology, has to do with moral values, particularly values related to economic distribution such as economic justice beliefs and egalitarianism vs. individualism. Ideological self-placement (1-10) and attitudes toward redistribution are the variables most commonly used in the literature as proxies for egalitarianism. It has been empirically demonstrated in almost all countries that citizens who define themselves as leftist, and those who are positive to redistribution, are more prone to support the WS than are their counterparts. Although egalitarianism and economic position are related, both factors work independently from each other, (i.e.independently of income, left-wing people are more likely to support welfare policies than right-wing people.)

These general determinants are one of the main findings of micro-level studies. However, a great deal of effort has also been made to study these attitudes at the macro-level. Comparative studies contend that the legitimacy of the WS varies across countries (Ferrera, 1993). Several authors have tried to explain this fact through country variables such as the degree of industrialization (Evans, 1995), level of inequality (Forma, 1999), organization of the political system (Haller et al., 1990), economic traditions (Bonoli, 2000), political trust (Svallfors, 2002), national values (Giddens, 2000), and the historical roots of social institutions (Lin, 2005). None of these avenues has been successful.

The most recent path of research on the topic is founded in neo-institutionalism (North, 1999; Pierson, 1993). This research suggests a simple yet appealing explanation: the diverging levels of popular support for welfare programs could be due to the fact that these programs are organized in very different ways across countries. Most studies attempt to test this idea using Esping-Andersen's typology of WS's to seek a relationship between the country's welfare regime and the level of support for its main welfare programs. The results are contradictory: some authors find a relationship between welfare regimes and WS legitimacy (Gundelach, 1994; Gevers et.al, 2000; Andreß \& Heien, 2001), others deny it exists (Bean \& Papadakis, 1998; Bonoli, 2000), and others think that it may exist but with important outliers (Svallfors, 2000).

The main problem of these studies is that they seek to explain attitudes towards particular programs through a presumably all-inclusive independent variable such as welfare regime. Citizens' opinions can be influenced by how welfare programs are organized 
but, if this is so, we need to determine what specific characteristics are influential, and through what mechanisms they are translated to people's attitudes. To do this, the work of some longstanding and recent social policy experts is helpful.

One of the founding fathers of comparative welfare studies, Richard Titmuss, reflected 50 years ago on the risks involved by private or occupational welfare schemes. He explained that:

As they grow and multiply they come into conflicts with the aims and unity of social policy; for in effect (whatever their aims may be) their whole tendency at present is to divide loyalties, to nourish privilege, and to narrow social conscience as they have already done in the United States, in France and in Western Germany (Titmuss, 1955:164).

Some 40 years later, Titmuss' insight was retrieved by three prominent scholars of comparative welfare states. Walter Korpi (1998) \& Joakim Palme (1998), and EspingAndersen (2000) theorized on the relationship between a welfare program's degree of integration and its popular legitimacy. They asserted that integration is one the characteristics of a welfare program that strongly influences citizens' opinions.

For these authors, integration is not defined as legal access to welfare programs, but as the "real" use of those programs. For instance, how many people actually depend on public welfare programs for the provision of healthcare, education, or to maintain a good standard of living when they are old or unemployed? To be integrative, a program must be universally accessible and provide a level of benefits and services which match the expectations of the middle and upper-middle classes. Integration means that public welfare programs are used as a main source of provision not only by lower classes (that have no other option), but also by groups who could opt out of the system. In Korpi's words:

The encompassing ${ }^{1}$ model includes all citizens in the same programs. By giving basic security to everybody and offering clearly earning-related benefits to all economically active individuals, in contrast to the targeted and basic security models, the encompassing model brings low-income groups and the better-off citizens into the same institutional structures. Because of its earning-related benefits, it is likely to reduce the demand for private insurance. Thus, the encompassing model can be expected to have the most favourable outcomes in terms of the formation of class coalitions that include manual workers as well as the middle classes (Korpi 1998:672)

From this quotation, it is clear that the hypothetical mechanism that links a welfare program's degree of integration with its popular legitimacy is related to the generation of

\footnotetext{
${ }^{1}$ In Korpi's typology (1998), welfare states with a high degree of integration are included in the Encompassing Model.
} 
cross-class coalitions in support of the program. In this paper we aim to find empirical support for this idea. As such, our hypotheses are elaborated below. If highly integrative welfare programs achieve a higher legitimacy than other programs because they generate cross-class coalitions of support, then our data should show that:

$\mathrm{H1}$. International variation in support for welfare programs is statistically significant and partially due to some country-level variable.

H.2. There is a relationship between the level of legitimacy of welfare programs and the composition of their support basis. Assuming that the lower classes will always support the WS because of their almost total dependency on public provision, this hypothesis implies that some countries have pushed middle and upper-middle class support for the WS to levels close to those typical of the lower classes.

H.3. There is a relationship between the level of integration of a program and its legitimacy (aggregate support). Programs that integrate the middle and upper-middle classes will achieve higher legitimacy than those used mainly by the lower sectors of the population.

Hypotheses 1 to 3 present an interesting model to explain international variation in support for the WS. However, these hypotheses are entirely focused on only one of the two determinants of attitudes to the WS: self-interest. Since we know that ideology is of enormous importance in understanding what people think of welfare policies, we have built an alternative (or complementary) hypothesis:

H.2.b. Some countries present higher levels of support for the WS because they have managed to build an inter-ideology consensus regarding the WS. This implies that in some countries people who hold individualistic values support the WS as much (or nearly as much) as those embracing egalitarian values. In other words, high legitimacy is achieved when the WS loses, in the eyes of citizens, the ideological or moral purpose of helping the poor and building a more egalitarian society.

\section{Data and Methods}

\section{a) Selection of countries}

The following criteria were used in the selection of sample countries: a) maximum variation in welfare organization; b) the inclusion of extreme cases regarding one or both of the phenomena to be studied (either attitudes to the WS or organizational characteristics of their welfare programs); and c) data availability. To comply with these criteria, we selected at least two countries from each of the now widely accepted welfare regimes (Esping-Andersen, 1990): Sweden and Norway (Social-democrat); France and Germany 
(Corporatist); UK, USA, Australia, Ireland (Liberal), plus Canada as a heterogeneous WS; and Spain and Italy as representative of the Mediterranean regime (Bonoli, 1997; Ferrera, 1996; Moreno, 2002).

\section{b) Data sources and variables}

The economic indicators of welfare programs included in the last section of the paper have been produced by the Organization for Economic Cooperation and Development (OECD). Apart from these indicators, all the data used throughout the analysis were drawn from a survey carried out by the International Social Survey Programme (ISSP) in 1985, 1990, 1996 and 2006 titled "The Role of Government." This article is primarily based on data from the third wave of the survey.

\section{Dependent variables}

Of the questions included in the survey we have chosen three items:

P. "On the whole, do you think it should or should not be the government's responsibility to:

Provide healthcare for the sick.

Provide a decent standard of living for the old.

Provide a decent standard of living for the unemployed."

The response options were: Definitely should be; Probably should be; Probably should not be; and Definitely should not be.

Although these questions may seem very general, studies on the dimensions of welfare attitudes reveal these questions to be the best indicators of support for the WS. This result is based on factor analyses using dozens of questions related to the different aspects of the WS. The analyses determined that attitudes towards the WS have several dimensions: citizen opinions are not the same when we ask them about the scope, level of expenditure, or consequences of welfare policies. However, the same factor analyses indicate that there is also a single underlying factor that can be understood as general support or rejection of state intervention on welfare, called "welfarism". All questions regarding welfare issues correlate with this baseline factor and the questions that correlate the most are those that we have chosen (Van Oorschot \& Meuleman, 2009).

Independent variables

In our analyses, we use both micro-level and macro-level independent variables. For micro-level independent variables, we use indicators of the two factors that determine attitudes to the WS: self-interest and ideology. Following other studies, we 
selected a question on attitudes towards redistribution as a proxy for the ideology determinant:

What is your opinion on the following statement: "It is the responsibility of government to reduce the differences in income between people with high incomes and those with low incomes."

The possible response options were: 1. Agree strongly; 2. Agree; 3. Neither agree nor disagree; 4. Disagree; and 5. Disagree strongly.

We also use normal procedures by employing the relative economic position of each individual as a proxy of "self-interest." This measure was built by transforming the family income of each individual into percentages of the national median. The variable ranges from "- 0.6 " (family income equal or below $60 \%$ the national median) to " +0.6 " (family income $60 \%$ or more above the national median). In addition to this, sex is included in all regression models as a control since we know that in most countries women are typically more positive towards the WS than are men.

We use two types of macro-level variables to explain popular support for welfare programs: a) variables that refer to characteristics of each particular program; and b) variables that refer to the organization of the complete welfare system.

The program-specific attributes whose effects on legitimacy will be tested are: a) degree of integration (how many people really use and depend on the program); b) extension or range of provisions of the program; and c) economic effort devoted to the program.

Because our hypotheses focus on the effect of integration on legitimacy, we already have detailed reasons for its inclusion. Regarding the other two attributes, we believe that extensive programs that cover a wider range of needs within its domain (e.g., healthcare systems that provide not only medical attention but also medicines) can deepen citizens' loyalties and, hence, strengthen the program's legitimacy. Economic effort is measured as the share of GDP devoted to a program. It can be significant either as an indicator of the importance given to a welfare program by national governments, or as a (poor) proxy for the quality of provisions.

We are further interested in the potential effects on legitimacy of characteristics of the welfare system. First of all, the overall cost of welfare systems is important to address simply because expensive welfare systems may depress public support for all programs. Secondly, the size of the WS must be examined because larger institutions may have greater effects on public attitudes. A large WS implies, at least, the existence of many loyal bureaucrats as well as several channels to influence social perceptions of "normality" (King, 1987; Gundelach, 1994; Pierson, 1993, Svallfors, 2000; Andreß \& Heien, 2001).

The OECD data used as a proxy for each of the five macro-level factor are presented in table 1. 
Table 1.

Characteristics of welfare programs/systems that can affect legitimacy (OECD data)

\begin{tabular}{|c|c|c|c|}
\hline & Healthcare & Old-age pensions & $\begin{array}{l}\text { Unemployment } \\
\text { protection }\end{array}$ \\
\hline Integration & $\begin{array}{l}\text { Legal coverage. } \\
\text { Expenditure on private } \\
\text { health insurance as a } \\
\text { percentage of total health } \\
\text { expenditure. }\end{array}$ & $\begin{array}{l}\text { Replacement rate of } \\
\text { public old-age pensions } \\
\text { for low, middle and high } \\
\text { incomes }\end{array}$ & $\begin{array}{l}\text { Replacement rate of } \\
\text { unemployment benefits } \\
\text { (average of } 3 \\
\text { situations) }\end{array}$ \\
\hline Extension & $\begin{array}{l}\text { Public expenditure on } \\
\text { health as a percentage of } \\
\text { total (public and private) } \\
\text { expenditure on health }\end{array}$ & $\begin{array}{l}\text { Expenditure on "Other } \\
\text { services to old-age" } \\
\text { (apart from cash } \\
\text { transfers) as a \% of GDP }\end{array}$ & $\begin{array}{l}\text { Expenditure on "Active } \\
\text { labor market policies" } \\
\text { as a } \% \text { of GDP }\end{array}$ \\
\hline Intensity & $\%$ GDP on public healthcare & $\begin{array}{l}\% \text { GDP on old-age } \\
\text { programs }\end{array}$ & $\begin{array}{l}\% \text { GDP on } \\
\text { unemployment } \\
\text { protection programs }\end{array}$ \\
\hline Cost of the WS & \multicolumn{3}{|c|}{$\begin{array}{l}\text { Percentage of salary devoted to taxes and social contributions by low, middle and } \\
\text { high income groups. }\end{array}$} \\
\hline Size of the WS & \multicolumn{3}{|c|}{$\%$ GDP devoted to social expenditure. } \\
\hline
\end{tabular}

\section{Statistical METHOdS}

Most of the analyses performed are based on multilevel linear regression models where individuals are units of Level 1 and countries are units of Level 2. To analyze the form of welfare consensus, models include three Level 1 variables: sex, relative economic position, and ideology and random slopes for relative economic position and ideology2. To determine which program's characteristics correlate with legitimacy, we include the Level 2 variables listed in table 1.

Multilevel models are a useful tool to separate variance in attitudes to the WS into two components; variance attributed to individual characteristics; and variance attributed to country-level factors. However, our analysis includes a small number of countries, and the generalization of results to other nations should be made with caution.

\footnotetext{
${ }^{2}$ As a verification strategy we have also run ordinal logistic regression models with the countries included as dummy variables and the interaction coefficients "country*ideology" and "country*relative economic position". Results were coherent with multilevel models and are not included here.
} 


\section{International VARiation in atTitudes to the Welfare State}

While it may be counter-productive to our argument, it is necessary to point out that one of the main trends one notices when analyzing comparative data on WS attitudes is that there is often a large and stable consensus (as opposed to a variation in attitudes) in support of state intervention in welfare. Graphs 1-3 present answers to three of the questions that are generally used as indicators of basic support for the existence of core welfare programs: healthcare, old-age pensions, and unemployment. These graphs are helpful in that they illustrate differences over time and cross-culturally as they include answers from five separate countries.

The countries included in these graphs were selected exclusively for reasons of data availability. Apart from being rich Western countries, they constitute a heterogeneous mix with regards to their welfare structure and recent economic and political developments. The heterogeneity of our sample makes the similarities in welfare attitudes even more interesting. As can be seen, support for state intervention to guarantee healthcare and old-age pensions is higher than $80 \%$ in all countries. This support has been consistent since 1985. In the case of state intervention to guarantee a decent standard of living for the unemployed, attitudinal variation is much more significant, both among countries and across time. Although the majority of each country's population is in favor of some public protection for the unemployed, we are speaking of percentages between 50 and $70 \%$.

Interestingly, the extended and somewhat stable legitimacy of the WS is an undeniable fact. But Graphs 1-3, like so many others that one can find on this topic, were made by collapsing response categories and may be slightly misleading regarding the international homogeneity of support for welfare policies. Tables 2, 3 and 4 present the disaggregated answers to questions on state responsibility in welfare for $1996^{3}$.

The tables for health care and pensions show that those who think that the government should not intervene (probably not + definitely not) account for a small minority in every country $(0.8 \%$ in Spain and Norway to $11.7 \%$ in the USA for healthcare and $0.8 \%$ in Ireland to $13.2 \%$ in the USA for pensions). Greater disparity is found among the pro-welfare groups, who can be strongly or mildly convinced of the virtues of state intervention. For example, in Italy, Ireland, Norway, Spain and the UK, more than $70 \%$ of the population believes that the government "definitely should" intervene in these areas. Others show mild support. For instance, in Australia, Germany and the USA, the majority of supporters chose the "probably should be the responsibility of government" option. Cross-country variation in attitudes towards programs that help the unemployed is larger.

\footnotetext{
${ }^{3}$ The tables exclude respondents who chose "don't know" or "no answer." Since these percentages are extremely low in every country, this decision does not imply an important loss of information. When adding the missing cases, "don't know" and "no answer", the percentage in the question on health care ranges from $0.5 \%$ to $6.8 \%$ depending on the country, from $0.3 \%$ to $5.5 \%$ for old-age pensions, and from $2 \%$ to $10 \%$ regarding unemployment protection.
} 
Graph 1.

Support for health care programs

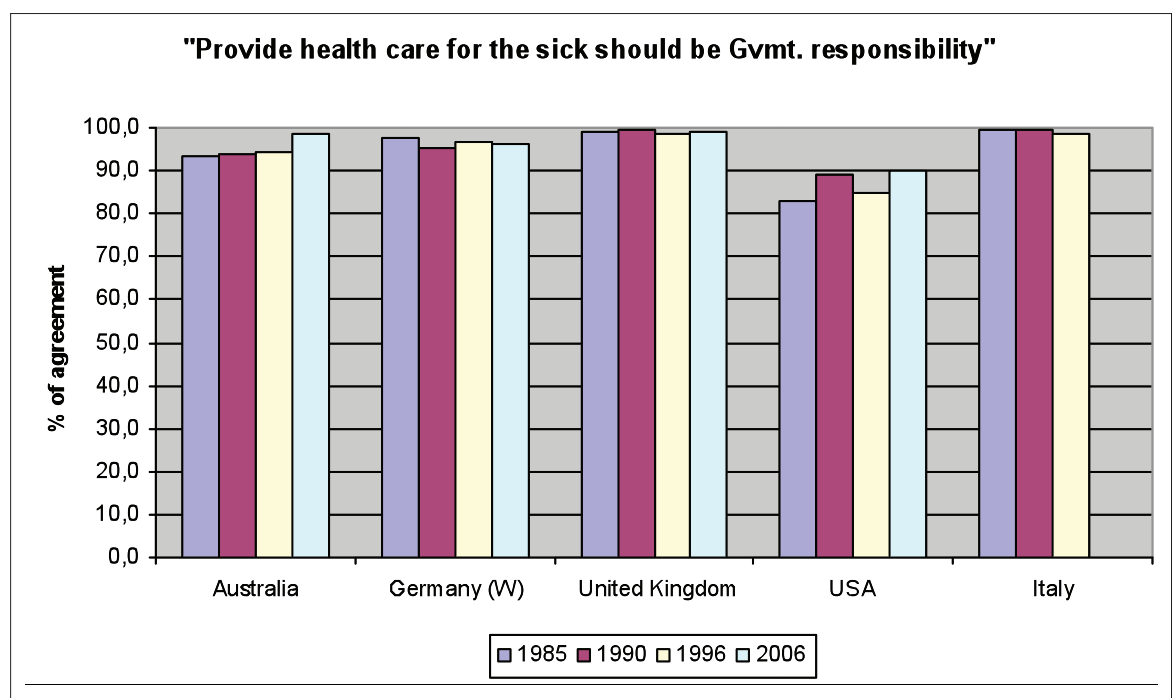

Data source: ISSP "The Role of Government I, II, III, IV" (1985, 1990, 1996, 2006). The percentage in the Y axis is the sum of respondents answering "Definitely should be the responsibility of government" and those who answered "Probably should be the responsibility of government".

Graph 2.

Support for public pension systems

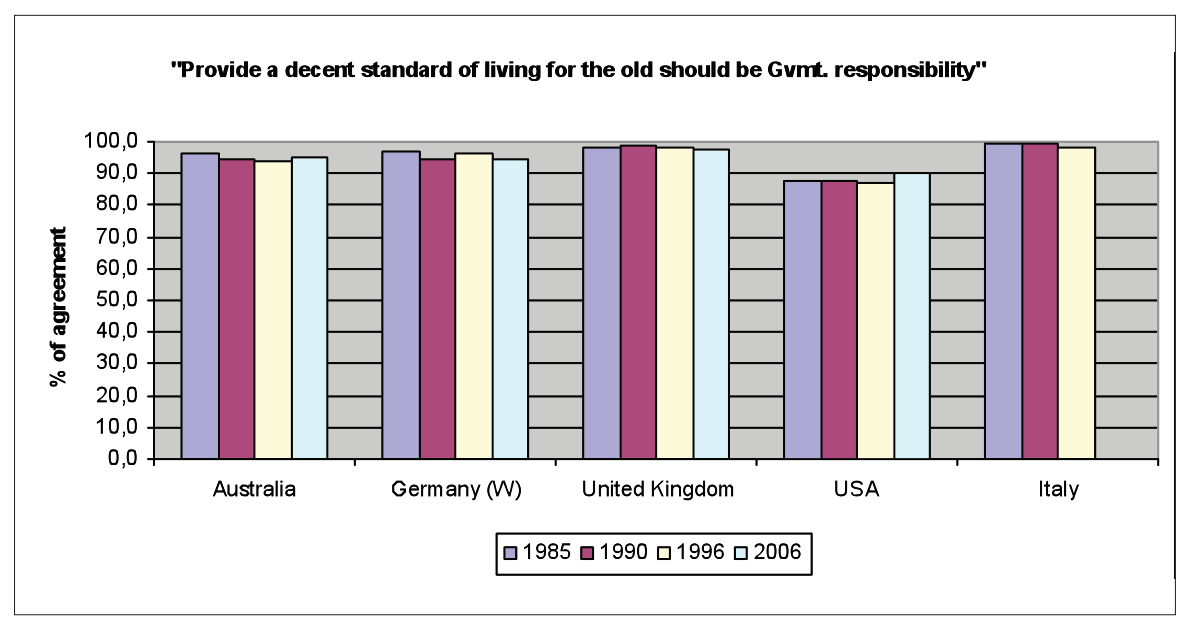

Data source: ISSP "The Role of Government I, II, III, IV" (1985, 1990, 1996, 2006). The percentage in the Y axis is the sum of respondents answering "Definitely should be the responsibility of government" and those who answered "Probably should be the responsibility of government". 
Graph 3.

Support for unemployment benefit systems

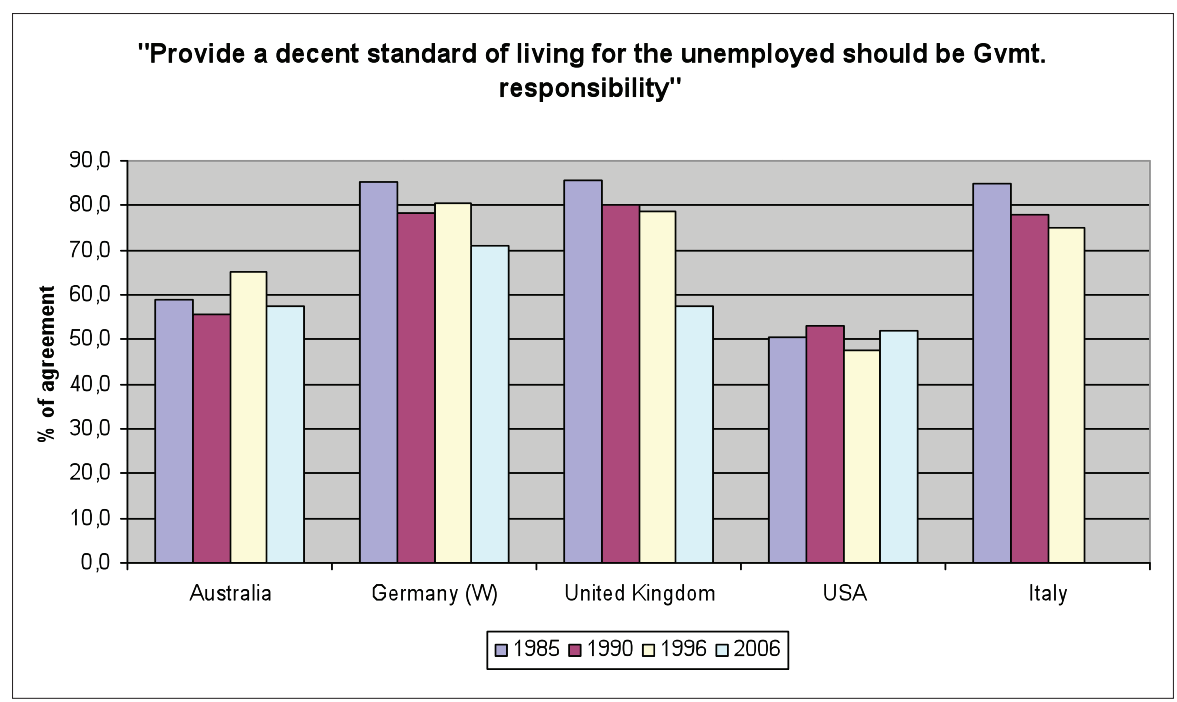

Data source: ISSP "The Role of Government I, II, III, IV" (1985, 1990, 1996, 2006). The percentage in the Y axis is the sum of respondents answering "Definitely should be the responsibility of government" and those who answered "Probably should be the responsibility of government".

Table 2.

Attitudes towards public health care programs

Should it be the responsibility of government to...?

\begin{tabular}{|c|c|c|c|c|c|c|}
\hline & & \multirow[b]{2}{*}{$\begin{array}{l}\text { Definitely } \\
\text { should be }\end{array}$} & \multicolumn{3}{|c|}{ Provide health care for the sick } & \multirow[t]{2}{*}{ Total } \\
\hline & & & $\begin{array}{l}\text { Probably } \\
\text { should be }\end{array}$ & $\begin{array}{l}\text { Probably } \\
\text { should not be }\end{array}$ & $\begin{array}{c}\text { Definitely } \\
\text { should not be }\end{array}$ & \\
\hline \multirow[t]{11}{*}{ Country } & AUS & $42.4 \%$ & $51.7 \%$ & $5.4 \%$ & $.4 \%$ & $100.0 \%$ \\
\hline & D-W & $50.6 \%$ & $46.0 \%$ & $2.9 \%$ & $.5 \%$ & $100.0 \%$ \\
\hline & GB & $82.0 \%$ & $16.4 \%$ & $1.2 \%$ & $.3 \%$ & $100.0 \%$ \\
\hline & USA & $38.5 \%$ & $46.1 \%$ & $11.7 \%$ & $3.7 \%$ & $100.0 \%$ \\
\hline & 1 & $81.0 \%$ & $17.6 \%$ & $1.0 \%$ & $.4 \%$ & $100.0 \%$ \\
\hline & IRL & $74.3 \%$ & $24.7 \%$ & $.8 \%$ & $.1 \%$ & $100.0 \%$ \\
\hline & $\mathrm{N}$ & $87.4 \%$ & $11.8 \%$ & $.5 \%$ & $.3 \%$ & $100.0 \%$ \\
\hline & $S$ & $71.1 \%$ & $25.3 \%$ & $2.5 \%$ & $1.2 \%$ & $100.0 \%$ \\
\hline & CDN & $63.4 \%$ & $31.9 \%$ & $3.4 \%$ & $1.3 \%$ & $100.0 \%$ \\
\hline & E & $80.9 \%$ & $18.3 \%$ & $.7 \%$ & $.1 \%$ & $100.0 \%$ \\
\hline & $\mathrm{F}$ & $54.5 \%$ & $34.7 \%$ & $7.3 \%$ & $3.5 \%$ & $100.0 \%$ \\
\hline Total & & $64.5 \%$ & $31.2 \%$ & $3.4 \%$ & $1.0 \%$ & $100.0 \%$ \\
\hline
\end{tabular}

Source: ISSP, 1996. 
Table 3.

Attitudes towards public old-age pension systems

Should it be the responsibility of government to...?

\begin{tabular}{|c|c|c|c|c|c|c|}
\hline & & \multicolumn{4}{|c|}{ Provide a decent standard of living for the old } & \multirow[t]{2}{*}{ Total } \\
\hline & & $\begin{array}{l}\text { Definitely } \\
\text { should be }\end{array}$ & $\begin{array}{l}\text { Probably } \\
\text { should be }\end{array}$ & $\begin{array}{c}\text { Probably } \\
\text { should not be }\end{array}$ & $\begin{array}{l}\text { Definitely } \\
\text { should not be }\end{array}$ & \\
\hline \multirow[t]{11}{*}{ Country } & AUS & $37.4 \%$ & $56.7 \%$ & $5.5 \%$ & $.4 \%$ & $100.0 \%$ \\
\hline & D-W & $47.9 \%$ & $48.1 \%$ & $3.6 \%$ & $.4 \%$ & $100.0 \%$ \\
\hline & GB & $71.0 \%$ & $26.3 \%$ & $2.3 \%$ & $.4 \%$ & $100.0 \%$ \\
\hline & USA & $38.4 \%$ & $48.3 \%$ & $9.9 \%$ & $3.3 \%$ & $100.0 \%$ \\
\hline & I & $76.1 \%$ & $21.9 \%$ & $1.7 \%$ & $.3 \%$ & $100.0 \%$ \\
\hline & IRL & $76.6 \%$ & $22.6 \%$ & $.5 \%$ & $.3 \%$ & $100.0 \%$ \\
\hline & $\mathrm{N}$ & $85.9 \%$ & $13.2 \%$ & $.5 \%$ & $.4 \%$ & $100.0 \%$ \\
\hline & $S$ & $69.2 \%$ & $28.5 \%$ & $1.5 \%$ & $.8 \%$ & $100.0 \%$ \\
\hline & CDN & $49.4 \%$ & $41.8 \%$ & $7.0 \%$ & $1.7 \%$ & $100.0 \%$ \\
\hline & $\mathrm{E}$ & $79.6 \%$ & $19.4 \%$ & $.9 \%$ & $.2 \%$ & $100.0 \%$ \\
\hline & $\mathrm{F}$ & $54.4 \%$ & $39.3 \%$ & $4.8 \%$ & $1.6 \%$ & $100.0 \%$ \\
\hline Total & & $61.0 \%$ & $34.7 \%$ & $3.5 \%$ & $.8 \%$ & $100.0 \%$ \\
\hline
\end{tabular}

Source: ISSP, 1996.

Here we find countries where significant portions of the population are not in favor of this public policy (around 35\% in Australia and Canada and 52\% in the USA).

Tables are important because they contain the raw data and give us an accurate picture of the extent of variation. However, when using surveys, raw data is frequently a synonym of "too much data". The excessive number of percentages becomes cumbersome when looking for patterns or even when ordering the countries in terms of higher to lower popular support for the WS.

To simplify our data, we have computed a weighted mean of answers: ( $4 \mathrm{x} \%$ who chose "Definitely should") $+(3 \times \%$ of "Probably should" $)+(2 \times \%$ "Probably not") $+(1$ $x \%$ "Definitely not"). This method is better than collapsing categories because it takes into account variation between "strong" and "mild" supporters. In addition, this approach provides us with an index of legitimacy that ranges from 100 to 400 and has a clear interpretation: it takes the value of 100 if $100 \%$ of the population states that the government "definitely should not" be responsible for a welfare area, and takes the value of 400 when the opposite is true: $100 \%$ of the population thinks that a welfare area "definitely should be" the government's responsibility. Using this weighted mean makes it easier to order our eleven countries according to the legitimacy of their welfare programs. 
Table 4.

Attitudes towards unemployment protection systems

Should it be the responsibility of government to...?

\begin{tabular}{rrccccc}
\hline \multicolumn{6}{c}{} & \multicolumn{2}{c}{ Provide a decent standard of living for the unemployed } & Total \\
\hline & & $\begin{array}{c}\text { Definitely } \\
\text { should be }\end{array}$ & $\begin{array}{c}\text { Probably } \\
\text { should be }\end{array}$ & $\begin{array}{c}\text { Probably } \\
\text { should not be }\end{array}$ & $\begin{array}{c}\text { Definitely } \\
\text { should not be }\end{array}$ & \\
\hline Country & AUS & $8.9 \%$ & $56.2 \%$ & $30.3 \%$ & $4.5 \%$ & $100.0 \%$ \\
\hline D-W & $16.9 \%$ & $63.5 \%$ & $15.6 \%$ & $4.0 \%$ & $100.0 \%$ \\
\hline GB & $28.4 \%$ & $49.4 \%$ & $15.3 \%$ & $7.0 \%$ & $100.0 \%$ \\
\hline USA & $12.8 \%$ & $34.9 \%$ & $33.1 \%$ & $19.2 \%$ & $100.0 \%$ \\
\hline I & $30.8 \%$ & $44.9 \%$ & $15.2 \%$ & $9.1 \%$ & $100.0 \%$ \\
\hline IRL & $39.7 \%$ & $51.9 \%$ & $6.8 \%$ & $1.5 \%$ & $100.0 \%$ \\
\hline N & $40.8 \%$ & $51.9 \%$ & $6.3 \%$ & $1.1 \%$ & $100.0 \%$ \\
\hline S & $38.3 \%$ & $52.2 \%$ & $7.3 \%$ & $2.2 \%$ & $100.0 \%$ \\
\hline CDN & $16.6 \%$ & $51.2 \%$ & $23.6 \%$ & $8.6 \%$ & $100.0 \%$ \\
\hline Total & $59.2 \%$ & $34.6 \%$ & $4.8 \%$ & $1.3 \%$ & $100.0 \%$ \\
\hline
\end{tabular}

Source: ISSP, 1996. AUS: Australia, D-W: Germany (West), GB: Great Britain, USA: United States; I: Italy; IRL: Ireland, N: Norway, S: Sweden, CDN: Canada, E: Spain, F: France.

Table 5 shows the ranking of countries regarding the legitimacy of welfare programs. Ordinal logistic regression models including the countries as a set of dummies confirm that the order of countries is statistically significant.

Regarding the importance of a country's effect on welfare attitudes, multilevel models tell us that variation across countries accounts for $12 \%$ of the total variation in attitudes towards healthcare and old-age programs ( $\mathrm{M0}$ in tables $8,9,10)$. This cross-country variation also accounts for $16 \%$ of the variation in attitudes towards unemployment benefits. This is a significant amount if we compare it with similar studies. Therefore, our first hypothesis finds empirical support, but we are unable to move forward in our analysis without first dealing with an alternative explanation.

Previously, we mentioned that one of the conclusions reached by scholars who conduct comparative studies on welfare attitudes is that citizens vary in their support for welfare programs depending on their egalitarianism (the ideology factor) and their direct interest in the existence of welfare programs (self-interest factor). Because of this, it is possible that cross-country variation in support for the WS has nothing to do with the form 
Table 5.

Welfare programs legitimacy ranking

\begin{tabular}{l|c|l|c|l|c}
\hline \multicolumn{2}{c|}{ Table 5.a } & \multicolumn{2}{c|}{ Table 5.b } & \multicolumn{2}{c}{ Table 5.c } \\
\hline Norway & Healthcare & \multicolumn{3}{c}{ Unemployment } \\
Spain & 386 & Norway & 385 & Spain & 352 \\
UK & 380 & Spain & 378 & Norway & 332 \\
Italy & 380 & Ireland & 376 & Ireland & 330 \\
Ireland & 379 & Italy & 373 & Sweden & 326 \\
Sweden & 374 & UK & 371 & France & 310 \\
Canada & 366 & Sweden & 366 & UK & 301 \\
Germany* & 354 & Germany* & 344 & Italy & 296 \\
France & 347 & France & 342 & Germany* & 293 \\
Australia & 337 & Canada & 336 & Canada & 273 \\
USA & 336 & Australia & 331 & Australia & 270 \\
Average & 319 & USA & 322 & USA & 241 \\
\hline
\end{tabular}

Source: prepared by the author with ISSP 1996 data. * Only West Germany.

of welfare programs and is instead caused by the different distribution of egalitarianism and poverty across countries. For example, countries where more citizens hold egalitarian values will present a higher overall support for the WS independently of how welfare programs are organized. In order to establish the validity of this alternative explanation, new multilevel models were built. The reference models in Tables 8, 9 and 10 include the ideology, relative economic position, and sex of the individuals. This reduces the variation attributed to country level, but it does not make it disappear. In fact, if the eleven countries had the same economic distribution and the same percentages of individualists and egalitarians, international differences in attitudes towards welfare programs would be only $12 \%$ smaller for healthcare programs, $16 \%$ smaller for old-age pensions, and $25 \%$ smaller for unemployment benefits.

In this section, we have demonstrated that welfare programs have varying degrees of legitimacy and that part of the explanation for that variation lies in some specific country characteristic. Our hypotheses maintain that this country characteristic is the degree of integration of welfare programs. Following Korpi, Palme and Esping-Andersen, integration is translated into high levels of popular support through the generation of classcoalitions. Our own complementary hypothesis suggests that integration could impact legitimacy by creating cross-ideology coalitions. The next section is devoted to analyzing the extent to which these mechanisms actually work. 


\section{How is High LegitTMACy Achieved?}

\section{a) Cross-class consensus and welfare programs legitimacy}

Seeing that welfare programs have more supporters in some places causes one to question where this "extra support" comes from. For instance, which groups support the WS in one country, but are not positive towards this institution in other countries? According to hypothesis 2.a, the behavior of middle and upper-middle classes determines whether or not a WS will have low or high legitimacy. A welfare program will achieve a high level of popular support when it manages to bring middle classes up to the level of support of low classes.

In order to put this hypothesis to test, we have built multilevel models with three individual variables: ideology, relative economic position, and sex. We also include random slopes to determine if the effect of relative economic position on attitudes differs across countries. Since we are controlling for ideology and sex, we compare the effect of economic position on attitudes towards welfare programs across people from different countries, but of the same sex and similar ideology.

The models are similar to simple linear regressions with interactions between country and relative economic position, but the multilevel technique has the advantage of calculating the correlation between the random slope and the constant. This coefficient enables us to know whether certain countries achieve more support for welfare policies because they have managed to diminish the attitudinal gap between low income and middle-high income groups.

The models tell us various things. First of all, the effect of economic position on attitudes towards the WS varies across countries. In other words, the gap in level of support for welfare programs between those with low and high incomes differs in size depending on the country. Secondly, low income people are more similar across countries in their attitudes towards welfare programs than are high income people ${ }^{4}$. Low income people tend to support welfare programs independently of the country where they live, while the levels of support of high income people depend more on their country of residence. The larger heterogeneity of middle classes is consistent with the argument that these groups are key to achieving a highly legitimized WS. However, we must mention that even if low income groups are more homogeneous than high income groups at the international scale, levels of support among low income groups also vary across countries. Finally, the coefficient for the correlation between the random slope and the constant indicates that the lower the importance of income to determine attitudes to a welfare program, the higher its aggregate level of popular support . However, the coefficient is not statistically

\footnotetext{
${ }^{4}$ To reach this conclusion we computed the same models for those with incomes equal or below $60 \%$ of the national median, on the national median, and $60 \%$ or more above the national median. The models are not shown here.
} 
Table 6.

Multilevel models with level-1 independent variables and random slopes for the variable "relative economic position"

Fixed part:

\begin{tabular}{lcccccccc}
\hline Healthcare & Coef. & P $>$ Z & Unemployment & Coef. & $P>z$ & Pensions & Coef. & $P>z$ \\
\hline Ec. Position & .0585746 & 0.044 & Ec. Position & .1551287 & 0.000 & Ec. Position & .0913612 & 0.001 \\
Sex & -.0490185 & 0.000 & Sex & -.0691173 & 0.000 & Sex & -.0557016 & 0.000 \\
Ideology & .0981942 & 0.000 & Ideology & .1666801 & 0.000 & Ideology & .0937479 & 0.000 \\
cons & 1.171907 & 0.000 & _cons & 1.588891 & 0.000 & _cons & 1.217702 & 0.000 \\
\hline
\end{tabular}

Random part:

\begin{tabular}{lccc}
\hline Healthcare & Estimate & {$[95 \%$ Conf. } & Interval] \\
\hline Sd(ec.position) & .0884743 & .0525185 & .1490465 \\
Sd__cons) & .2027524 & .1304178 & .3152065 \\
Corr(ec.postion,_cons) & .7660552 & .2349056 & .9449145 \\
Sd(Residual) & .5566257 & .5499629 & .5633694 \\
\hline & & & \\
\hline Unemployment & Estimate & {$[95 \%$ Conf. } & Interval] \\
\hline Sd(ec.position) & .055888 & .0255026 & .1224767 \\
Sd(_cons) & .2794458 & .1798195 & .4342685 \\
Corr(ec.position,cons) & .4125849 & -.3796732 & .8557164 \\
Sd(Residual) & .7152956 & .7066233 & .7240743 \\
\hline & & & \\
\hline Pensions & Estimate & {$[95 \%$ Conf. } & Interval] \\
\hline Sd(ec.position) & .0828598 & .0485381 & .1414506 \\
Sd(_cons) & .198492 & .1276681 & .3086055 \\
Corr(ec.position,cons) & .5777371 & -.0584887 & .8802044 \\
Sd(Residual) & .5515997 & .5450034 & .5582758 \\
\hline
\end{tabular}

For the 3 models: prob $>\mathrm{chi}^{2}=0.0000$.

Lrtest comparing with OLS regression: $P$ rob $>\mathrm{Chi}^{2}=0.0000$. Source: own elaboration. 
significant, indicating that the relationship is weak. Although this relationship works for the eleven countries in our sample, it cannot be extrapolated to other countries.

Ultimately, the general conclusion is that although welfare programs with high levels of popular support tend to have a consensus which is less fractured by economic reasons, this is not sufficient to explain why they reach such high levels of legitimacy. This contradictory finding can be clarified by looking at Graph 4 on healthcare. Graphs A1 and $A 2$ on pensions and unemployment, respectively, can be found in Appendix 2. To understand the graphs, we only need to know that:

- In the horizontal axis, we have the economic position of the individual $(-.60=$ family income $60 \%$ lower than the national median; $0=$ family income equal to national median; $+.60=$ family income $60 \%$ higher than the national median).

- The vertical axis shows the answer to the question on the desirability of state intervention in healthcare. It ranges from 1 -strongly agree to $4-$ strongly disagree (see the section on methodology).

- The line shows variation in support for state intervention in healthcare as we move from the lowest to the highest income positions.

Keeping this information in mind, and looking at the graphs, we can see that although the effect of economic position on attitudes towards welfare programs varies across countries, the most important difference lies in the baseline level of support. In countries with highly supported welfare programs, the level of support is high across all income positions. We also find differences between income groups in these countries, but they occur in addition to this high level of support. The opposite is also true: in countries where welfare programs have low legitimacy, support for the programs is low across all income positions. (e.g., Spaniards or Italians with high economic positions are more prone to support welfare programs than Australians or Germans with incomes below the poverty line).

The low legitimacy of some welfare programs is not due (or not primarily due) to the lack of support from middle and high incomes. This low legitimacy can instead be attributed to programs that do not achieve high levels of support even among low income groups. High legitimacy requires persuading middle and low classes. In light of our results, support among the low classes cannot be taken for granted. Therefore, the existence of cross-class similarities in welfare attitudes is not always reflective of a highly legitimized Welfare State.

\section{b) Inter-ideology consensus and welfare program legitimacy}

To test our second hypothesis, we built multilevel regressions similar to those in the preceding section but we now introduce a random slope for ideology instead of relative economic position. Since we are controlling for economic position and sex, our models compare the effect of ideology on attitudes towards welfare programs of people from different countries but of the same sex and similar economic position. 
Graph 4.

Attitudes towards public healthcare and economic position (conditioned by sex and ideology)

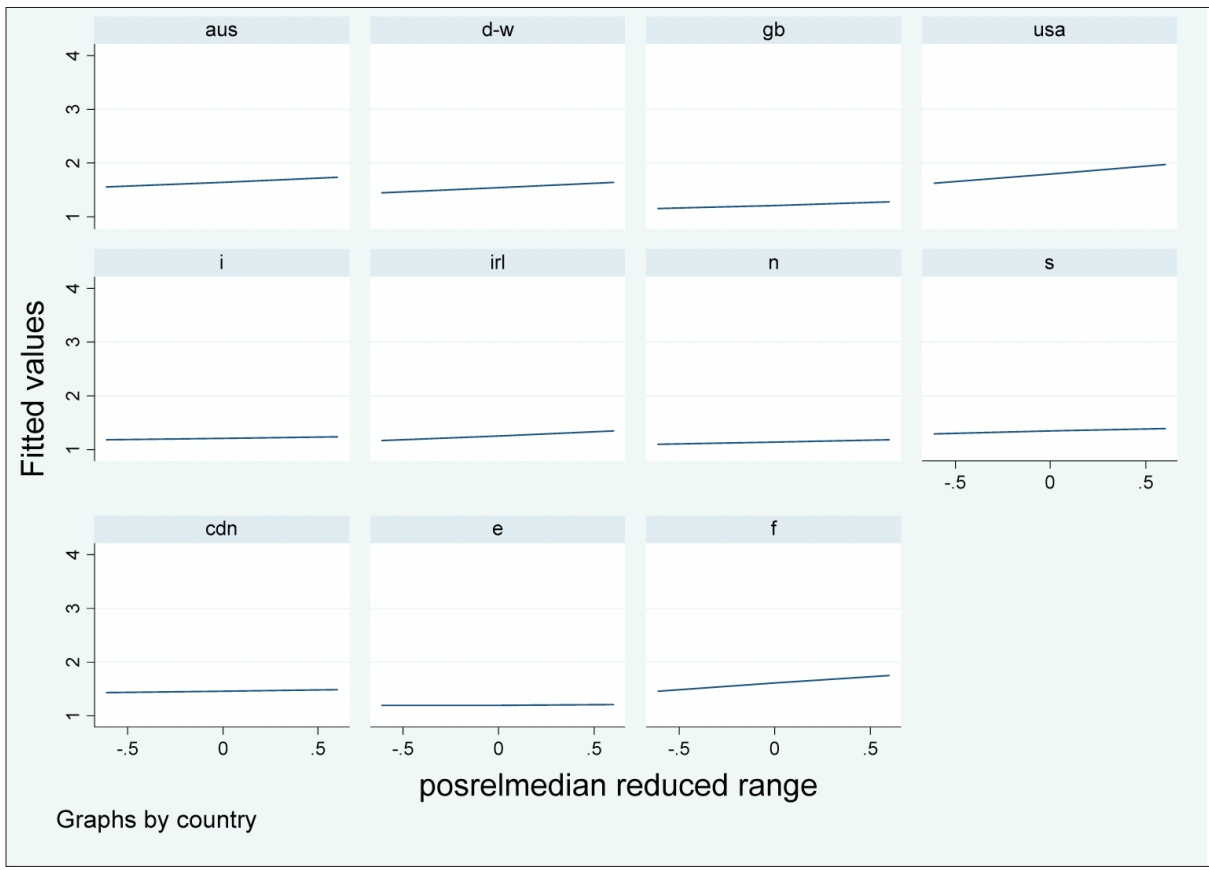

Aus: Australia, d-w: Germany (West), gb: Great Britain, usa: United States, i: Italy, irl: Ireland, n: Norway, s: Sweden, cdn: Canada, e: Spain, f: France.

Source: own elaboration with ISSP 1996 data.

The models presented in table 7 allow us to determine if the effect of ideology on attitudes towards welfare programs differs across countries and to what extent having a consensus with small ideological fractures equals having high legitimacy.

Our results provide support for the argument that high legitimacy is built through cross-ideology consensus. First, the models show that the effect of ideology on attitudes towards welfare programs varies: the gap in level of support between egalitarians and individualists is much larger in some countries than in others. Second, it is also confirmed that egalitarian people are more homogeneous across countries with respect to their attitudes towards the WS than are individualists. Specifically, people who hold egalitarian values tend to support the WS independently of the country where they live, while individualists appear to be more affected by their national context 5 . Finally, where

\footnotetext{
${ }^{5}$ To reach this conclusion we computed the same models for the strongly egalitarian and strongly individualistic. The models are not shown here.
} 
Table 7.

Multilevel models with level-1 independent variables and random slopes for "ideology"

Fixed part:

\begin{tabular}{lcccccccc}
\hline Healthcare & Coef. & P $>z$ & Pensions & Coef. & P $>z$ & Unemployment & Coef. & $P>z$ \\
\hline Ec. Position & .0587421 & 0.000 & Ec.position & .0912601 & 0.000 & Ec.position & .1483021 & 0.000 \\
Sex & -.0496454 & 0.000 & Sex & -.057121 & 0.000 & Sex & -.0686748 & 0.000 \\
Ideology & -.0393462 & 0.309 & Ideology & -.0556209 & 0.125 & Ideology & .0911756 & 0.048 \\
$\begin{array}{l}\text { Ideology } \\
\text { (sq.root) }\end{array}$ & .4243437 & 0.000 & $\begin{array}{l}\text { Ideology } \\
\text { (sq.root) }\end{array}$ & .4644193 & 0.000 & $\begin{array}{l}\text { Ideology } \\
\text { (sq.root) }\end{array}$ & .2427765 & 0.073 \\
cons & .7448628 & 0.000 & _cons & .7104322 & 0.000 & _cons & 1.673572 & 0.000 \\
\hline
\end{tabular}

Random part:

\begin{tabular}{|c|c|c|c|c|}
\hline Healthcare & Estimate & Std. Err. & [95\% Conf. & Interval] \\
\hline Var(ideology) & .0044981 & .0019913 & .0018889 & .0107115 \\
\hline Var(_cons) & .0486531 & .0208856 & .0209754 & .1128524 \\
\hline Cov(ideology,_cons) & .0127005 & .0059709 & .0009978 & .0244033 \\
\hline $\operatorname{Var}($ Residual) & .3040965 & .0037365 & .2968605 & .3115089 \\
\hline Old-age pensions & Estimate & Std. Err. & [95\% Conf. & Interval] \\
\hline Var(ideology) & .0026401 & .0012018 & .0010818 & .0064432 \\
\hline $\operatorname{Var}\left(\_c o n s\right)$ & .0446966 & .0191945 & .0192635 & .1037083 \\
\hline Cov(ideology,_cons) & .0085026 & .0042711 & .0001315 & .0168738 \\
\hline $\operatorname{Var}($ Residual) & .3011639 & .0036969 & .2940045 & .3084976 \\
\hline Unemployment & Estimate & Std. Err. & [95\% Conf. & Interval] \\
\hline Var(ideology) & .0030716 & .0014416 & .0012242 & .0077068 \\
\hline Var(_cons) & .0770112 & .0330658 & .0331955 & .1786604 \\
\hline Cov(ideology,_cons) & .0095623 & .0056922 & -.0015942 & .0207187 \\
\hline $\operatorname{Var}($ Residual) & .5075852 & .0063177 & .4953526 & .5201198 \\
\hline
\end{tabular}

For the 3 models: Prob >chi² $=0.0000$; Lrtest comparing with OLS regression: $\mathrm{Pr}>\mathrm{chi}^{2}=0.0000$. 
attitudinal differences between egalitarians and individualists regarding welfare programs are small, the programs tend to achieve the highest levels of popular support. The above conclusion holds true for healthcare and pensions (the coefficients are statistically significant thus indicating a clear relationship) but not for unemployment (the coefficients are positive but not statistically significant) ${ }^{6}$.

As in the previous section, graph 5 on healthcare presents these findings visually. Graphs A3 and A4 on pensions and unemployment can be found in Appendix 2.

On the horizontal axis, we find answers to the question used as an indicator of egalitarian/individualistic values, while on the vertical axis we find answers to the question on state intervention in healthcare. The blue line shows variation in support for state intervention in healthcare as we move from more egalitarian to more individualistic citizens.

The analyses presented in this section point out that the two hypotheses concerning the mechanisms that lead to high legitimacy are upheld by the data. However, the second hypothesis, addressing the need for cross-ideology coalitions to achieve high legitimacy is much clearer. In summary, we know that welfare programs with high popular support have achieved such support in two ways:

- They have managed to gain high levels of support from all income groups while also reducing the gap between attitudes of low and high income groups. However, it is more important to have a high baseline level of support across all income groups than to reduce the attitudinal gap between the rich and the poor.

- They have managed to obtain substantial support from people whose values are not especially close to WS objectives (people that reject redistribution). Welfare programs with high legitimacy have managed to diminish the attitudinal gap between egalitarian and individualistic people, ultimately increasing the support of individualists to levels closer to those typical of egalitarians.

\section{WHAT CHARACTERISTICS OF WELFARE PROGRAMS CORRELATE WITH HIGH LEGITIMACY?}

The final step of our analysis is to determine which characteristics of welfare programs correlate with high legitimacy. Our third hypothesis assumes that integration is crucial in activating the mechanisms that lead to high legitimacy. In order to test this last hypothesis, we must change the unit of analysis from the individual to the welfare program and quantify the legitimizing effect of attributes of the different programs.

To do so, three aspects of the programs and two of the whole WS will be tested. The program attributes are Integration, Extension and Economic effort devoted to the pro-

\footnotetext{
${ }^{6}$ Although the model coefficients are positive, this indicates a negative relationship due to the counter intuitive order of response categories for dependent variables.
} 
Graph 5.

Attitudes towards public healthcare and ideology (conditioned by sex and economic position)

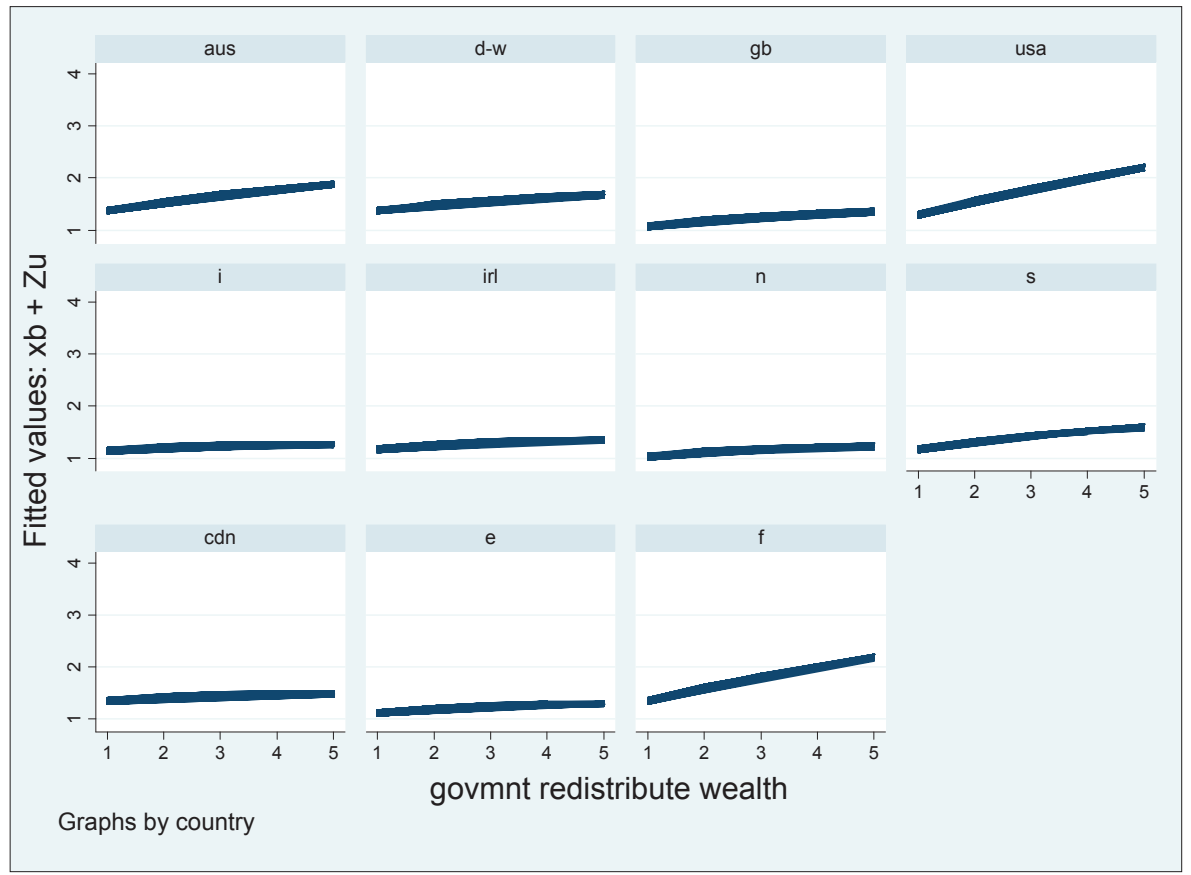

Aus: Australia, d-w: Germany (West), gb: Great Britain, usa: United States, i: Italy, irl: Ireland, n: Norway, s: Sweden, cdn: Canada, e: Spain, f: France.

Source: own elaboration with ISSP 1996 data.

gram, while the welfare system attributes are Cost and Size. The data used as proxies of each attribute are detailed in table 1.

With a large sample of countries it is possible to run a multilevel model that includes the five attributes (or level 2 variables) simultaneously. Since we are working with only eleven cases, we had to build a chain of multilevel models. The first model is the "empty" model. This is a model without variables that only indicates what proportion of the variation in attitudes towards the WS is due to country level. In the first part of the analysis we mentioned that a small fraction of international variation in attitudes is due to the fact that the variables affecting welfare attitudes are not equally distributed among the eleven societies under study. To account for this, all multilevel models include three individual variables as controls: ideology, relative economic position, and sex. In this way, they inform us about the effect of each program characteristic on legitimacy after controlling for the fact that some countries have more egalitarians or poor people than other countries. 


\section{a) Characteristics of healthcare programs and legitimacy}

The multilevel models for healthcare programs are presented in table 8. From these models, we learn that Extension and Integration are the only indicators that statistically correlate with legitimacy, the latter being the one that works best. The percentage of GDP spent on public health care and the cost and size of the WS have no impact on people's opinions to state intervention in healthcare.

Integration explains $73 \%$ of the country level variation in attitudes towards healthcare programs, while the indicator of extension, although strongly correlated, only explains $40 \%$. Both of these effects, integration and extension, clearly overlap. Graph 6 aids us in interpreting the model coefficients?

Graph 6.

Integration of public healthcare programs and legitimacy

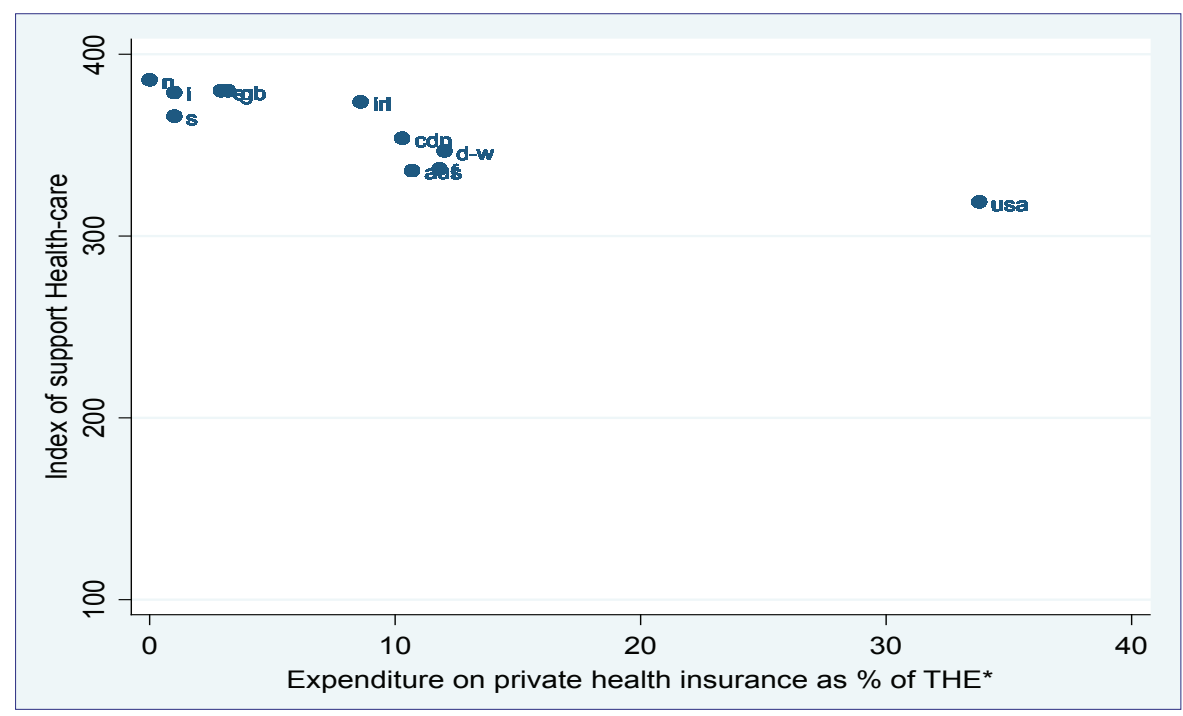

*THE: Total Health Expenditure; Aus: Australia, d-w: Germany (West), gb: Great Britain, usa: United States, i: Italy, irl: Ireland, n: Norway, s: Sweden, cdn: Canada, e: Spain, f: France.

${ }^{7}$ The graphs in this section do not derive from the fitted values of the multilevel models, but from simply plotting the legitimacy index of each program (table 5) against its value in the indicator of integration, extension, etc. 


\begin{tabular}{|c|c|c|c|c|c|c|}
\hline & 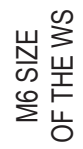 & 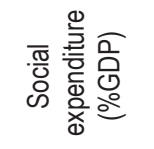 & 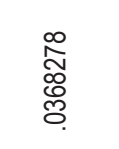 & 芦 & 事 & \\
\hline \multirow{10}{*}{ 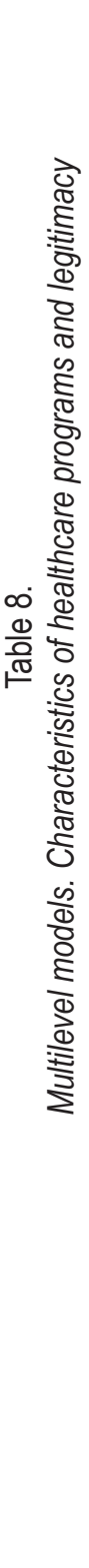 } & \multirow{3}{*}{$\sum^{n} \bar{d}$} & 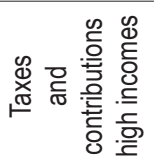 & $\begin{array}{l}\infty \\
\infty \\
\varnothing \\
0 \\
0\end{array}$ & 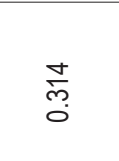 & 兄 & \\
\hline & & 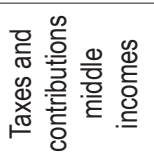 & $\begin{array}{l}\text { శ్ } \\
\text { O }\end{array}$ & 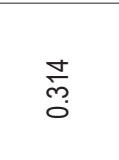 & 兄 & \\
\hline & & 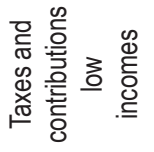 & 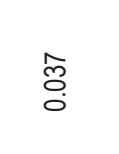 & ஜั & $\stackrel{\infty}{Z}$ & \\
\hline & 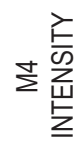 & 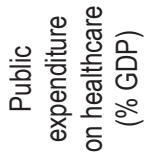 & 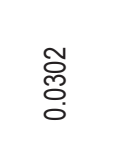 & 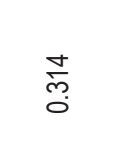 & 兄 & \\
\hline & 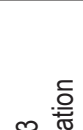 & 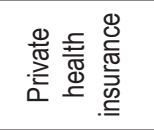 & $\stackrel{\sim}{\circ}$ & $\underset{\text { E. }}{0}$ & 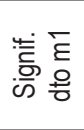 & 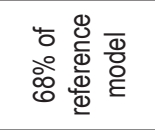 \\
\hline & $z \underset{\Phi}{\stackrel{\Phi}{\Phi}}$ & 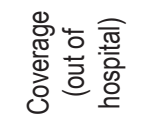 & 芦 & $\underset{\tilde{\sigma}}{\bar{\sigma}}$ & 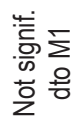 & \\
\hline & 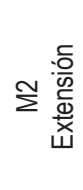 & 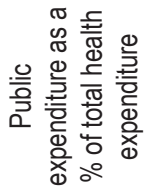 & $\begin{array}{l}\mathbb{Z} \\
\text { Oे }\end{array}$ & $\underset{\tilde{\sigma}}{\stackrel{\nabla}{0}}$ & 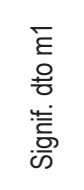 & 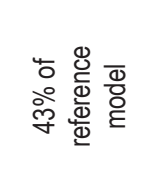 \\
\hline & 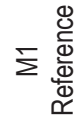 & 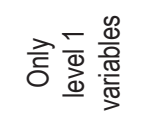 & 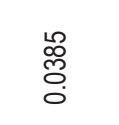 & $\underset{\tilde{\sigma}}{\tilde{\sigma}}$ & & 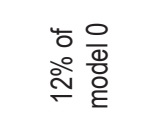 \\
\hline & $\stackrel{\circ}{\Sigma}$ & 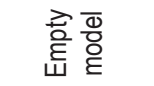 & 导 & స్ల & & \\
\hline & & & 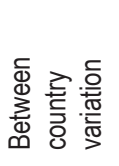 & 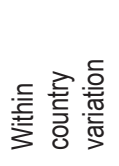 & 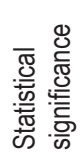 & 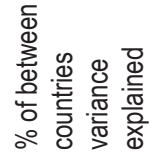 \\
\hline
\end{tabular}


In the top left corner of graph 6, we can identify countries whose public healthcare programs have the highest levels of popular support. Surprisingly, if we look at Table 5 , we can see that these countries do not belong to the same welfare regime, cultural tradition, or geographical area, but we can now confirm that all of them have highly integrative healthcare programs. This aids in explaining the common characteristics we find regarding attitudes towards healthcare among the citizens of these countries. Graph A5 in Appendix 2 plots the legitimacy of healthcare programs and its extension.

\section{b) Characteristics of public pension programs and legitimacy}

To evaluate the characteristics of public pension programs that shape citizens opinions, we build a new set of multilevel models (table 9). The models inform us that the legitimacy of old-age public programs does not depend on the cost of the WS for the taxpayer, the percentage of GDP a country spends on old-age protection, or the size of the complete WS. Only the indicator used to measure the extension of the program (expenditure on "other services to old-age") shows a significant relationship with aggregate support. However, when we plot this relationship, we are able to ascertain that two countries, Sweden and Norway, spend significantly more on this concept than the other countries. The relationship between extension of old-age pension programs and legitimacy is completely conditioned by these two cases.

None of the pension system characteristics included in the model have a clear enough relationship with legitimacy to be statistically significant. While the relationship may not be generalisable, plotting replacement rates against legitimacy provides us with some interesting information (graphs A6, A7 and A8 in Appendix 2). Apparently, having elevated replacement rates for low income groups has no impact on the overall legitimacy of public pension systems, while having high replacement rates for high income groups increases legitimacy. This result is logical since high income groups are more likely to exit the system to acquire private pensions unless high replacement rates guarantee them a level of income during old-age similar to the income level they were accustomed to while working.

\section{c) Characteristics of unemployment protection programs and legitimacy}

Similar to what occurred in the cases of healthcare and old-age pensions, legitimacy of unemployment policies does not depend on the economic effort the country makes towards protecting the unemployed. Even if we weight expenditure on this program by the percentage of unemployed in each country, the relationship is not significant. The amount of taxes and contributions paid by different income groups also has no impact on legitimacy, nor does the size of the complete welfare system.

Consistent with results on healthcare programs, the indicators that do correlate with popular support are those that act as proxies for the extension and integration of unemployment protection systems. Expenditure on active labor market policies (our 


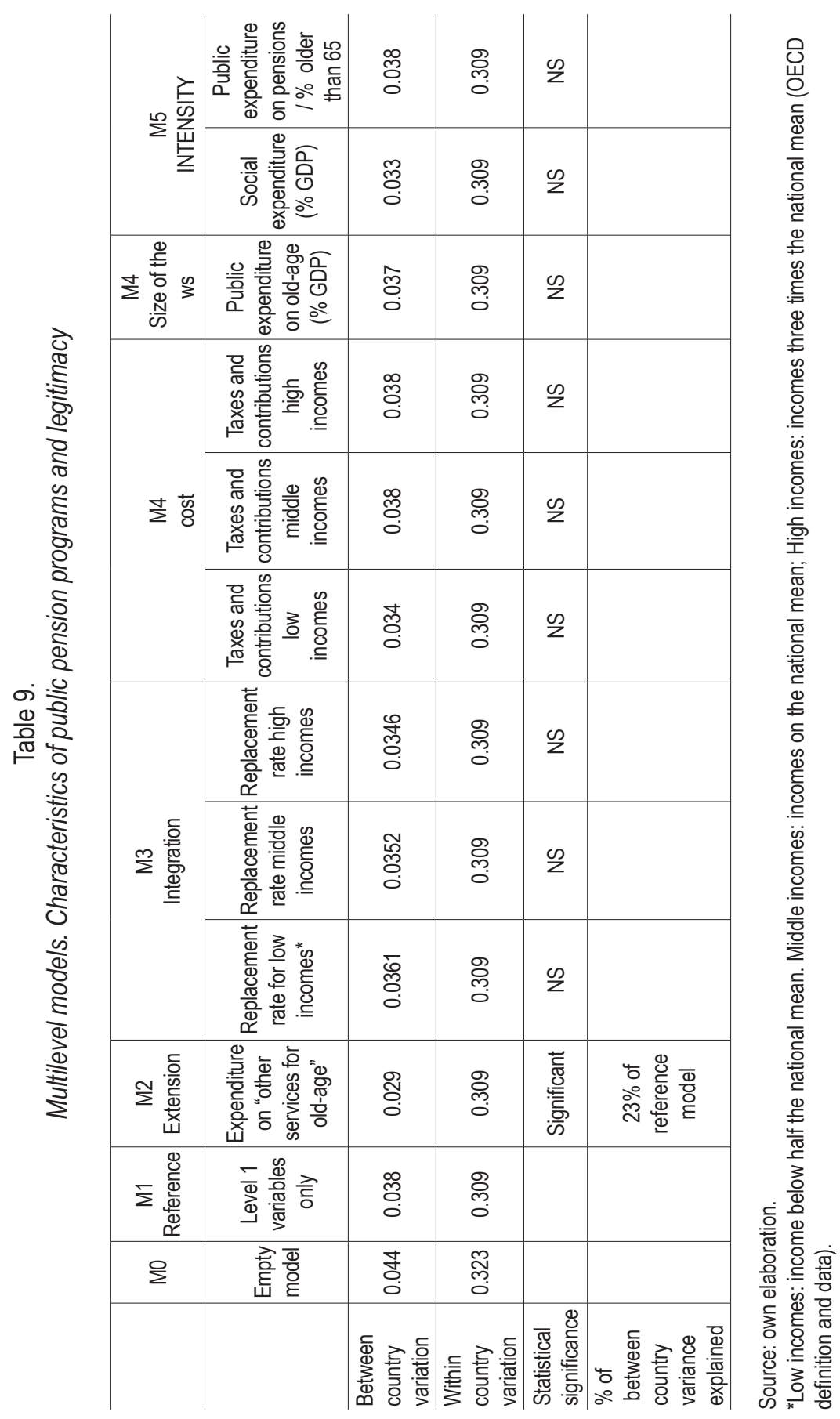




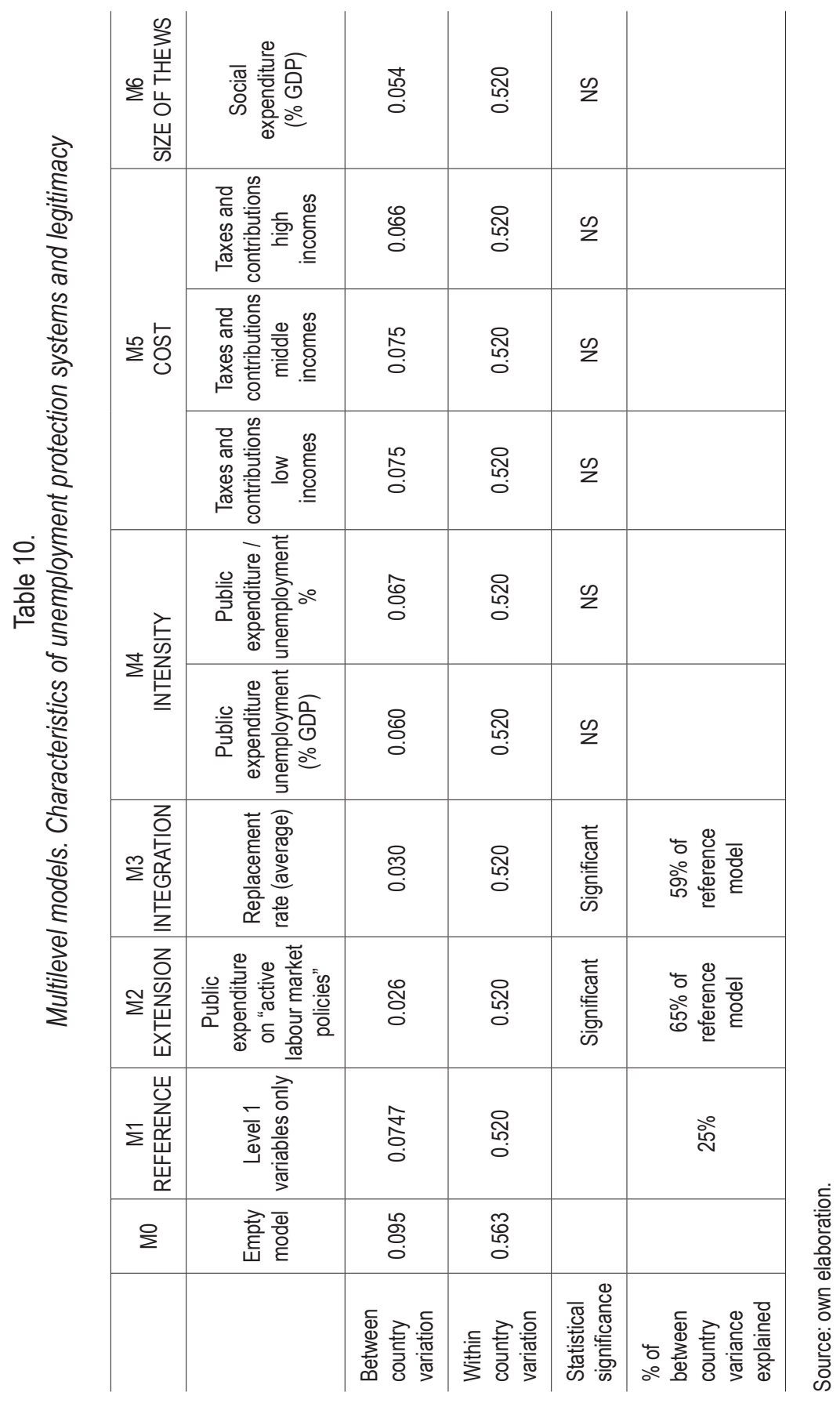


proxy for extension) and replacement rates of unemployment benefits (our proxy for integration) show a statistically significant relationship with the legitimacy achieved by state intervention in this area. As table 10 shows, expenditure on active labor market policies explains $65 \%$ of international variance, while replacement rate explains $59 \%$ of this variance (remember that we are speaking only about the portion of variance due to people living in different countries). These effects are inter-related and we would need to include both variables simultaneously in our models to understand how they really work. But with eleven cases, this is pushing our models a bit too far. What we can say is that unemployment public policies that give unemployed people both training and high replacement rates, present higher levels of popular support than those with opposing characteristics. Graphs plotting the legitimacy of unemployment protection versus their degree of integration and extension can be found in Appendix (graphs A9 and A10).

\section{Conclusions}

From the data and analyses presented here, we can conclude that welfare programs that achieve the highest legitimacy are those that cover a wide range of needs within its domain and are characterized by high integration.

This finding is independent of the welfare regime, geographical location, and cultural area of the country. We locate welfare programs with high legitimacy in each of the four welfare regimes in the Nordic, Continental, Anglo-Saxon or Mediterranean areas. What these programs have in common is a high level of integration and extension. Interestingly, neither the cost nor the size of the WS appear to influence people's opinions on the separate programs that make up the system. The lack of influence of the size and cost of the WS indicates that each welfare program depends entirely on itself for generating a strong and stable basis of support.

Our analyses support the existence of two mechanisms that link the attributes of a program with the opinions that citizens have towards them. Welfare programs characterized by high levels of extension and integration achieve high levels of popular support because:

- They raise the support levels of all income groups. We can assume that middle and upper-middle income groups support integrative programs more than others because they can benefit from them. These integrative programs are also favored by low income groups probably due to the fact that they offer the highest quality benefits, while lacking the stigmas typically associated with such programs.

- They increase the support of citizens who oppose economic redistribution. We can hypothesize that when a welfare program integrates all of the population among its beneficiaries, it loses its ideological component in the eye of many citizens and begins to be viewed as just another functional social institution. 
Walter Korpi (2000) has clearly demonstrated that integrative programs are more redistributive than means-tested ones. In light of our results, the higher redistributive power of integrative programs is not perceived by people who oppose redistribution. The mismatch between reality and popular perceptions appears to be, for once, positive to the WS.

\section{RefERENCES}

Andersen, J.G., Pettersen, P.A., Svallfors S. and Uusitalo Hannu. 1999. "The Legitimacy of the Nordic welfare states: Trends, Variations and Cleavages" Pp. 235-261 in Nordic Social Policy. Changing Welfare States, edited by Kautto et al. London: Routledge.

Andre, H.J. and Heien, T. 2001. "Four World of Welfare State Attitudes? A Comparison of Germany, Norway and the United States." European Sociological Review 17(4):337-356.

Arriba, A., Calzada, I. and Del Pino, E. 2006. Las actitudes de los españoles hacia el Estado del Bienestar. 1985-2005. Madrid: CIS.

Bean, C. and Papadakis, E. 1998. "A Comparison of Mass Attitudes towards the Welfare State in Different Institutional Regimes, 1985-1990." International Journal of Public Opinion 3: 211-236.

Bonoli, G. 1997. "Classifying Welfare States: a Two-dimension Approach." Journal of Social Policy 26(3):351-371.

Bonoli, G. 2000. "Public attitudes to social protection and political economy traditions in Western Europe." European Societies, 2(4):431-452.

Calzada, I. 2007. ¿Qué Estado del Bienestar queremos? Las opiniones de los ciudadanos sobre cómo son y cómo deberían ser nuestras políticas sociales. Zerbitzuan: Revista de Servicios Sociales del Gobierno Vasco 42: 103-114.

Esping-Andersen, G. 1990. The Three Worlds of Welfare Capitalism. London: Polity Press.

Esping-Andersen, G. 2000. Fundamentos sociales de las economías postindustriales. Barcelona: Ariel.

Evans, G. 1995. "Why is America Different? Explaining Cross-National Variation in Support for Welfare Redistribution." Working paper $\mathrm{N}^{\circ} 36$ of the Social \& Community Planning Research (SCPR). Nuffield College: Oxford.

Ferrera, M. 1993. Citizens and Social Protection. Main results from a Eurobarometer survey. Brussels: Commission of the European Communities.

Ferrera, M. 1996. "The 'southern model' of welfare in social Europe." Journal of European Social Policy 6(1):17-37.

Forma, P. 1999. Interests, Institutions and the Welfare State: Studies on Public Opinion Towards the Welfare State, STAKES (National Research and Development Centre for Welfare and Health) Research Report 102. Turku: University of Turku. 
Fraile, M. and Ferrer, M. 2004. "Explaining variation in public support for cuts in level of unemployment benefits spending across OECD countries." Working paper 2004/208. Madrid: Fundación Juan March.

Gevers, J., Gelissen, J., Arts, W. and Muffels, R. 2000. "Public healthcare in the balance: exploring popular support for healthcare systems in the European Union." International Journal of Social Welfare, 9:301-321.

Giddens, A. 2000. "Positive Welfare." 378-388 in The Welfare State Reader, edited by Pierson \& Castles. London: Polity Press.

Gundelach, P. 1994. "National Value Differences. Modernization or Institucionalization?." International Journal of Comparative Sociology 35(1-2):37-57.

King, D. S. 1987. "The state and the social structures of welfare in advanced industrial democracies." Theory and Society 16: 841-868.

Korpi, W. and Palme, J. 1998. "The Paradox of Redistribution and Strategies of Equality: Welfare State Institutions, Inequality and Poverty in the Western Countries." American Sociological Review 63:661-687.

Korpi, W. 2000. "Faces of Inequality: Gender, Class, and Patterns of Inequalities in Different Types of Welfare States." Social Politics 7(2):127-191.

Haller, M., Hoellinger, F. and Raubal, O. 1990. "Leviathan or Welfare State? The Role of Government in Six Advanced Western Nations." Pp.33-62 in Attitudes to Inequality and the Role of Government, edited by J.W. Becker et al. Rijswijk: Social and Cultural Planning Office.

Lin, Ka . 2005. "Cultural traditions and the Scandinavian Social Policy model." Social Policy \& Administration 39 (7):723-739.

Lipsmeyer, Ch.S. and Nordstrom, T. 2003. "East versus West: comparing political attitudes and welfare preferences across European societies." Journal of European Public Policy 10(3): 339-364.

Mishra, R. 1996. "The Welfare of Nations." Pp. 316-333 in States Against Markets, the Limits of Globalization, edited by Boyer \& Drache. London: Routledge.

Moreno, L. 2002. "Mediterranean Welfare and 'Superwomen'." Working paper 02-02 de la Unidad de Políticas Comparadas. Madrid: CSIC. (http://hdl.handle.net/10261/1496).

North, D.C. 1990. Institutions, Institutional Change and Economic Performance. New York: Cambridge University Press.

Pierson, P. 1993. "When Effect becomes cause. Policy Feedback and Political Change." World Politics 45:595-628.

Svallfors, S. 1997. "Worlds of Welfare and Attitudes to Redistribution: A Comparison of Eight Western Nations." European Sociological Review 13(3):283-304.

Svallfors, S. 2003. "Welfare Regimes and Welfare Opinions: a Comparison of Eight Western Countries." Social Indicators Research 64: 495-520. 
Svallfors, S. 2002. "Political trust and support for the Welfare State: Unpacking a supposed relationship." Pp. 184-205 in Restructuring the Welfare State, edited by Bo Rothstein \& Sven Steinmo. New York: Palgrave.

Taylor-Gooby, P., Hastie, C. and Bromley, C. 2003. "Querulous Citizens: Welfare Knowledge and the Limits to Welfare Reform." Social Policy and Administration 37(1):1-20.

Titmuss, R. 1955. "The Social Division of Welfare: Some Reflections on the Search for Equity." Ch. 6 in The Foundations of the Welfare State, edited by Goodin \& Mitchell. London: Edward Elgar.

Van Oorschot, W. and Meuleman, B. 2009. "Welfarism and the multidimensionality of welfare state legitimacy. Evidence from The Netherlands 2006 based on Confirmatory Factor Analyses." Paper presented at the ESPANET Conference, 18 September, Urbino.

INÉS CALZADA is BA in Sociology and BA in Communication Studies by the University of Salamanca. MsC in Social Research Methods for the Social Sciences by the London School of Economic and PhD Sociology by the University of Salamanca.She is now Juan de la Cierva Fellow at the Institute of Public Goods and Politics (Spanish National Research Council).

RECEIVED: 11 February 2010

ACCEPTED: 11 September 2011 


\section{Statistical Data. Appendix}

Graph A1.

Attitudes towards public pensions and relative economic position (conditioned by sex and ideology)

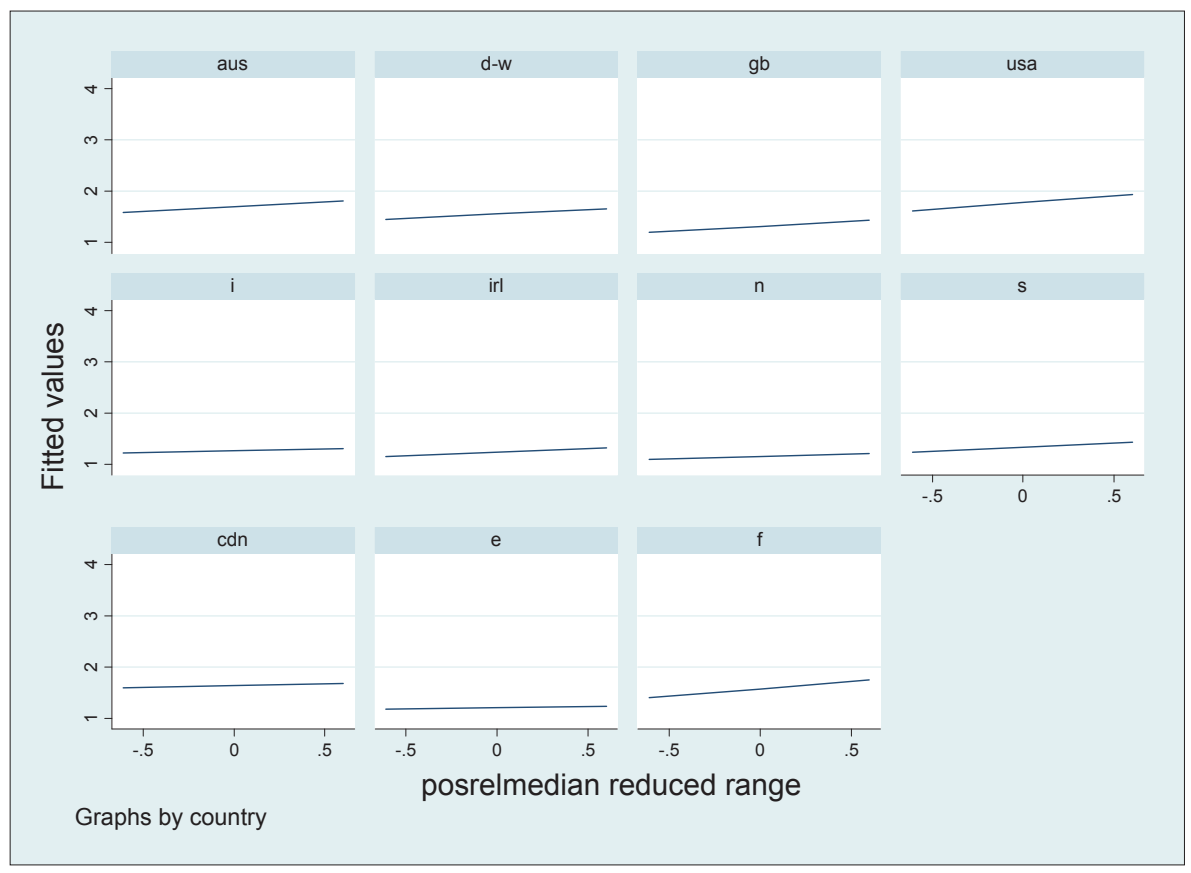

Aus: Australia, d-w: Germany (West), gb: Great Britain, usa: United States, i: Italy, irl: Ireland, n: Norway, s: Sweden, cdn: Canada, e: Spain, f: France. 


\section{Graph A2.}

Attitudes towards unemployment protection benefits and relative economic position (conditioned by sex and ideology)

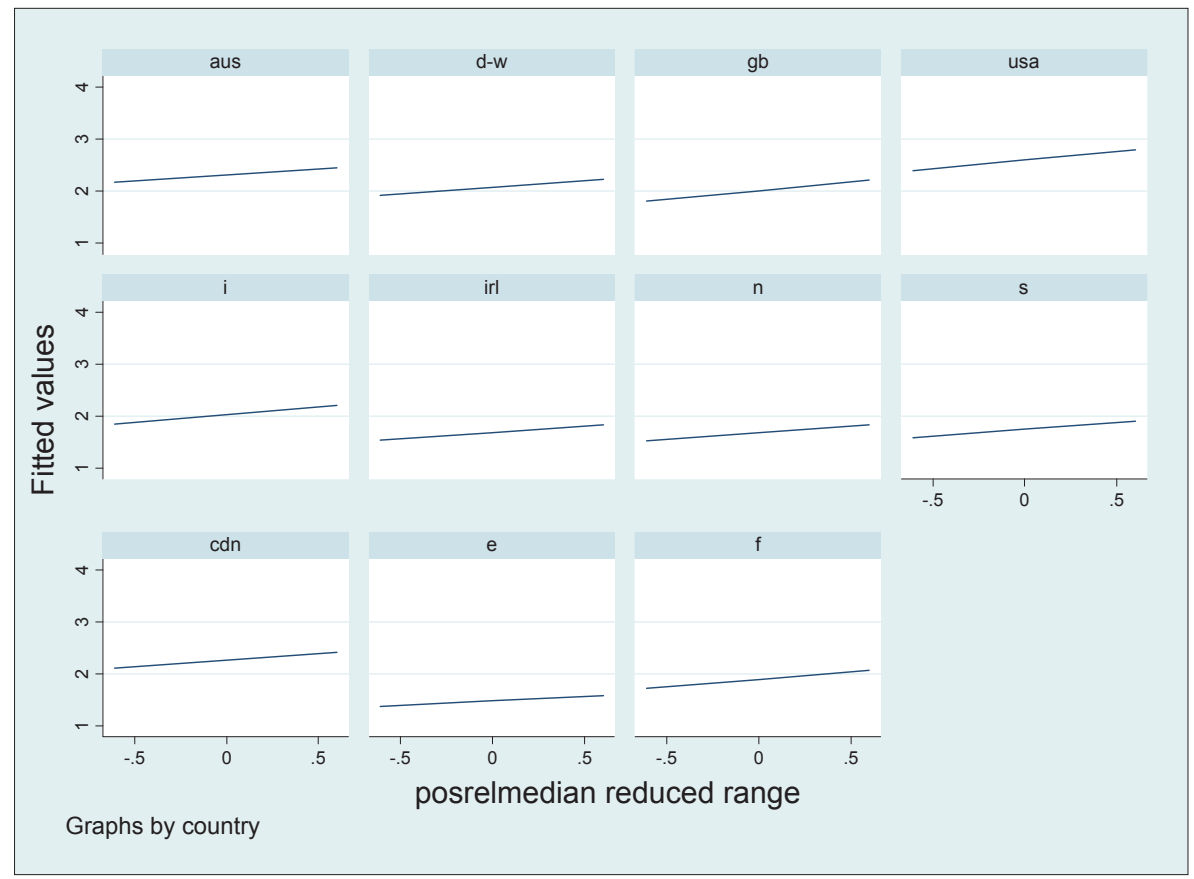

Aus: Australia, d-w: Germany (West), gb: Great Britain: United States, i: Italy, irl: Ireland, n: Norway, s: Sweden, cdn: Canada, e: Spain, f: France. 


\section{Graph A3.}

Attitudes towards public pensions and ideology

(conditioned by sex and economic position)

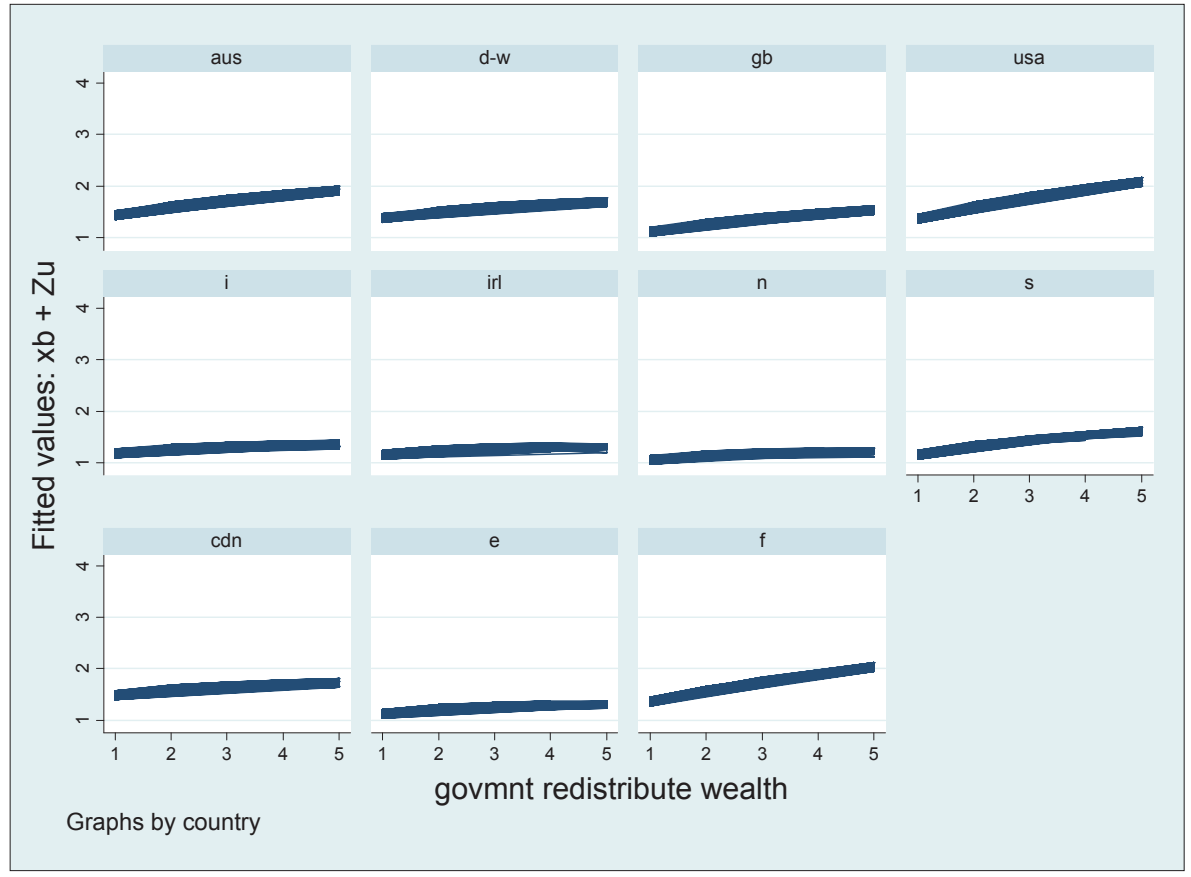

Aus: Australia, d-w: Germany (West), gb: Great Britain, usa: United States, i: Italy, irl: Ireland, n: Norway, s: Sweden, cdn: Canada, e: Spain, f: France. 
Graph A4.

Attitudes towards unemployment protection systems and ideology (conditioned by sex and economic position)

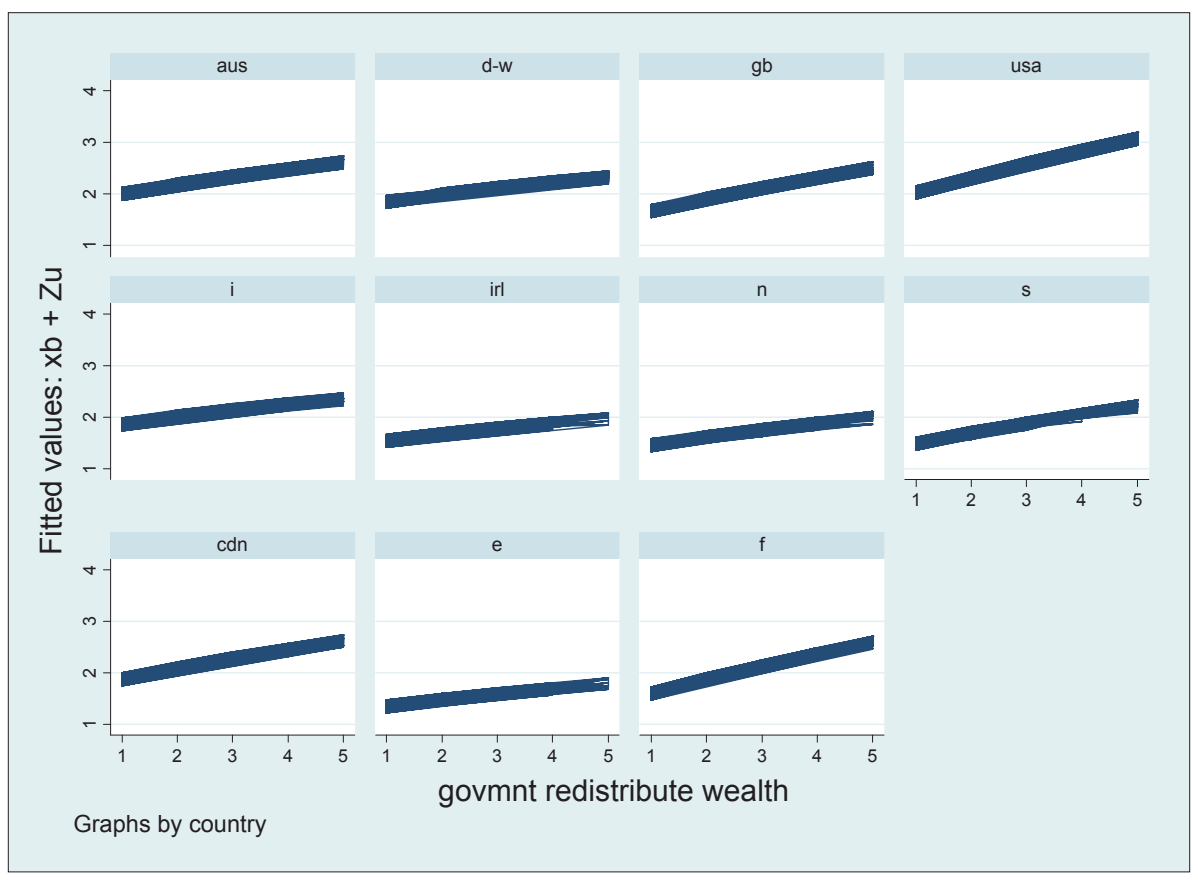

Aus: Australia, d-w: Germany (West), gb: Great Britain, usa: United States, i: Italy, irl: Ireland, n: Norway, s: Sweden, cdn: Canada, e: Spain, f: France. 
Graph A5.

Extension of the public healthcare program and legitimacy

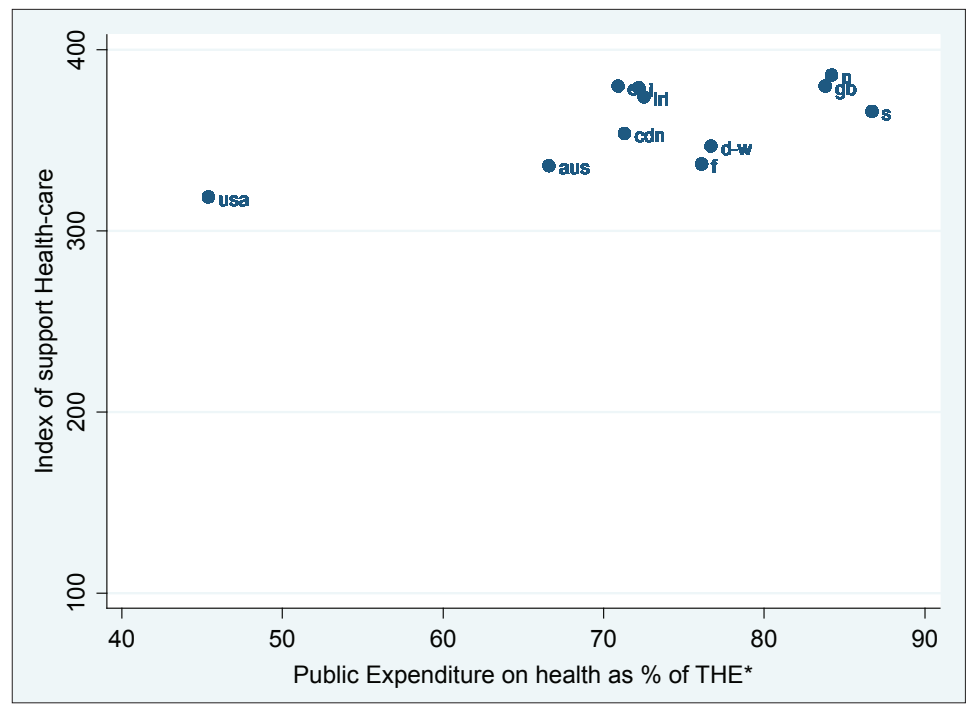

Graph A6.

Replacement rate of public pensions and legitimacy.

Rates for incomes of 0.5 the national average

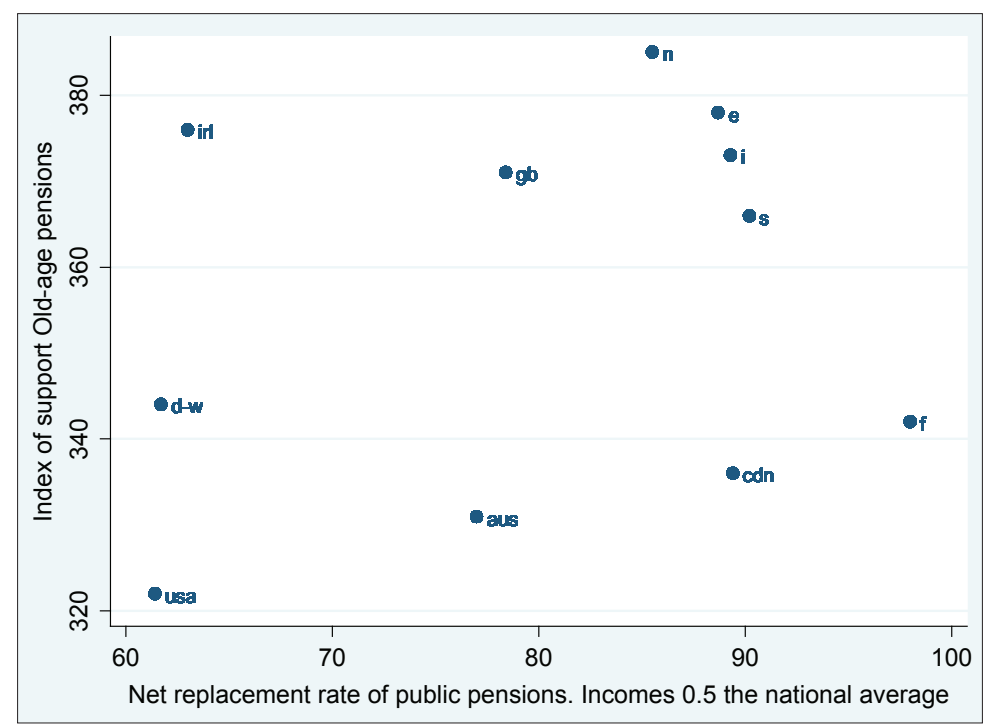

*THE: Total Health Expenditure; Aus: Australia, d-w: Germany (West), gb: Great Britain, usa: United States, i: Italy, irl: Ireland, n: Norway, s: Sweden, cdn: Canada, e: Spain, f: France. 


\section{Graph A7.}

Replacement rate of public pensions and legitimacy.

Rates for incomes on the national average

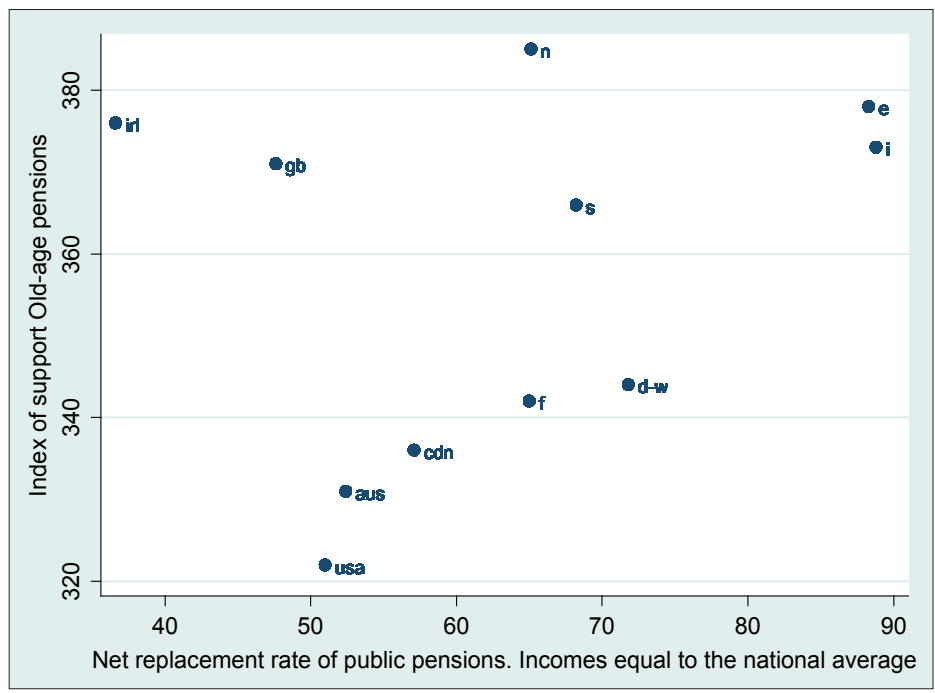

Graph A8.

Replacement rate of public pensions and legitimacy.

Rate for incomes of twice the national mean

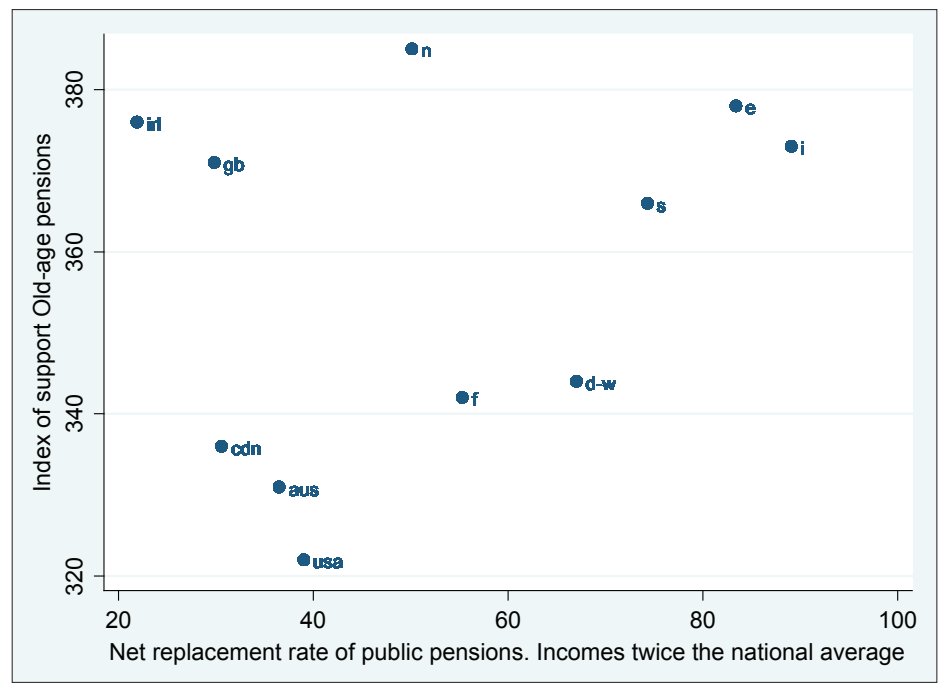

Aus: Australia, d-w: Germany (West), gb: Great Britain, usa: United States, i: Italy, irl: Ireland, n: Norway, s: Sweden, cdn: Canada, e: Spain, f: France. 
Graph A9.

Integration of unemployment benefits and legitimacy

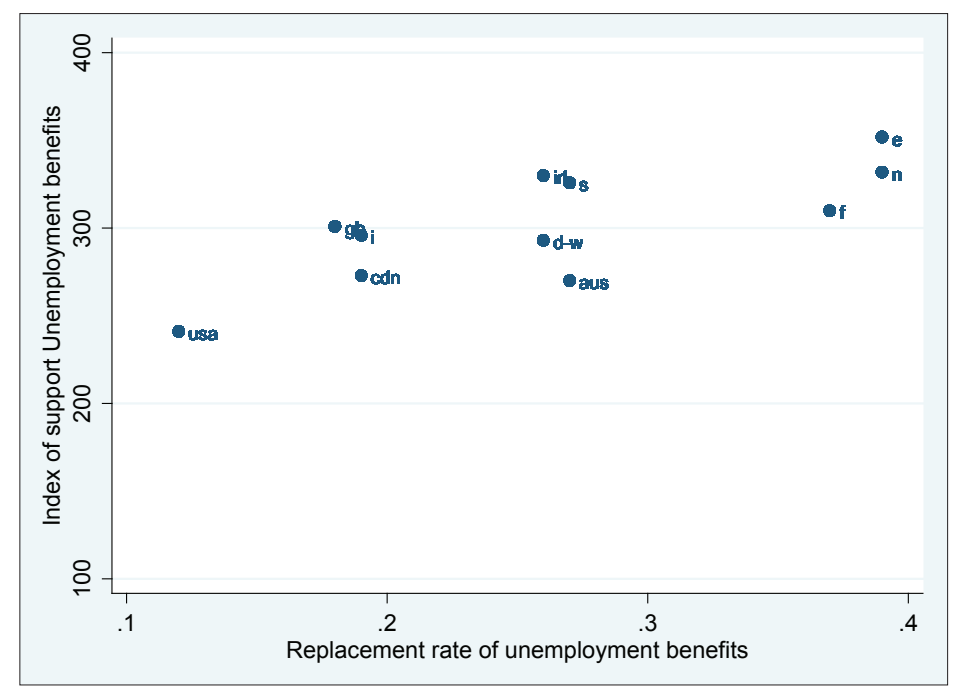

Graph A10.

Extension of unemployment protection and legitimacy

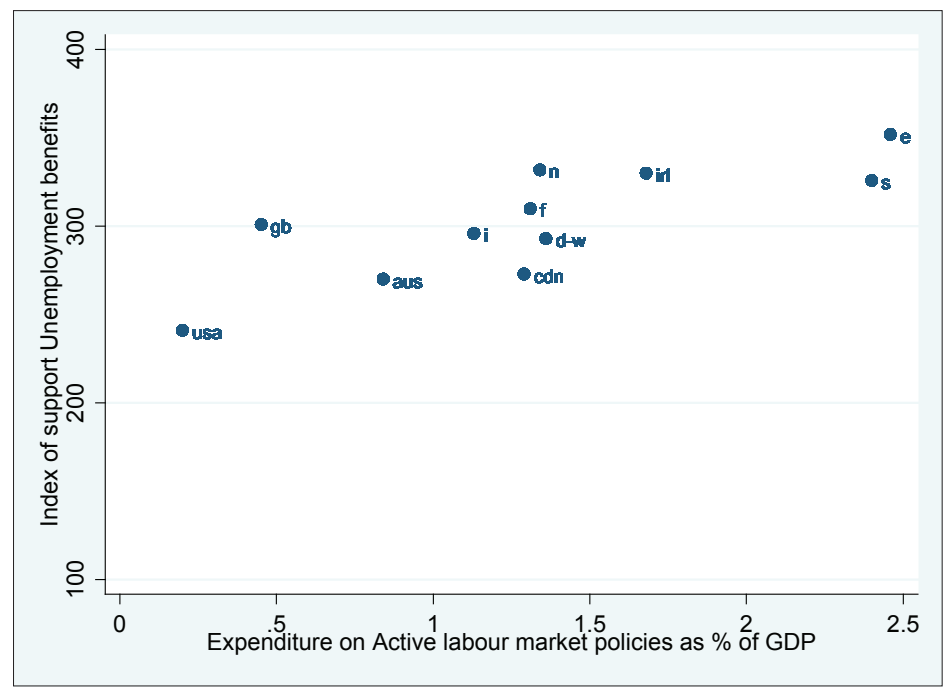

Aus: Australia, d-w: Germany (West), gb: Great Britain, usa: United States, i: Italy, irl: Ireland, n: Norway, s: Sweden, cdn: Canada, e: Spain, f: France. 